\title{
Radiolabelled Aptamers for Theranostic Treatment of Cancer
}

\author{
Umair Khalid ${ }^{1}$, Chris Vi ${ }^{1}$, Justin Henri ${ }^{1}$, Joanna Macdonald ${ }^{1}$, Peter Eu ${ }^{1,2}$, \\ Giovanni Mandarano ${ }^{1}$ and Sarah Shigdar ${ }^{1,3, *}$ \\ 1 School of Medicine Deakin University, Geelong, Victoria 3128, Australia; khalidu@deakin.edu.au (U.K.); \\ vchr@deakin.edu.au (C.V.); jhenri@deakin.edu.au (J.H.); J.macdonald@deakin.edu.au (J.M.); \\ peter.eu@deakin.edu.au (P.E.); giovanni.mandarano@deakin.edu.au (G.M.) \\ 2 Peter MacCallum Cancer Centre, Melbourne, Victoria 3000, Australia \\ 3 Centre for Molecular and Medical Research, Deakin University, Geelong, Victoria 3128, Australia \\ * Correspondence: sarah.shigdar@deakin.edu.au; Tel.: +61-03-5227-2846
}

Received: 1 November 2018; Accepted: 17 December 2018; Published: 24 December 2018

check for updates

\begin{abstract}
Cancer has a high incidence and mortality rate worldwide, which continues to grow as millions of people are diagnosed annually. Metastatic disease caused by cancer is largely responsible for the mortality rates, thus early detection of metastatic tumours can improve prognosis. However, a large number of patients will also present with micrometastasis tumours which are often missed, as conventional medical imaging modalities are unable to detect micrometastases due to the lack of specificity and sensitivity. Recent advances in radiochemistry and the development of nucleic acid based targeting molecules, have led to the development of novel agents for use in cancer diagnostics. Monoclonal antibodies may also be used, however, they have inherent issues, such as toxicity, cost, unspecified binding and their clinical use can be controversial. Aptamers are a class of single-stranded RNA or DNA ligands with high specificity, binding affinity and selectivity for a target, which makes them promising for molecular biomarker imaging. Aptamers are presented as being a superior choice over antibodies because of high binding affinity and $\mathrm{pH}$ stability, amongst other factors. A number of aptamers directed to cancer cell markers (breast, lung, colon, glioblastoma, melanoma) have been radiolabelled and characterised to date. Further work is ongoing to develop these for clinical applications.
\end{abstract}

Keywords: aptamers; cancer; chelating agents; diagnostics; EpCAM; molecular imaging; radiolabel; targeted imaging; theranostics; therapeutics

\section{Introduction}

Cancer continues to be a major cause of illness and social and economic burden. The numbers of cases increase yearly due to screening and enhanced detection methods. However, deaths arising from cancer are typically due to malignant and metastatic disease. Malignant tumours are capable of invading and spreading to surrounding tissue and to distant body sites, in a process known as metastasis, through the circulatory or lymphatic system, giving rise to secondary tumours [1]. At initial diagnosis, more than $50 \%$ of patients will have clinically detectable metastatic disease [2]. Metastatic tumours are largely responsible for cancer mortality, therefore, early tumour detection can improve prognosis [3]. Current modalities available for imaging tumour masses includes ultrasound, (X-ray) computed tomography (CT), magnetic resonance imaging (MRI) and positron-emission tomography (PET) [4] (Table 1). 
Table 1. The different methods of malignant tumour cell detection by current medical imaging modalities and its advantages and disadvantages. Source adapted from [4-12].

\begin{tabular}{|c|c|c|c|}
\hline $\begin{array}{c}\text { Medical } \\
\text { Imaging Tool }\end{array}$ & Method of Detection & Advantages & Disadvantages \\
\hline Ultrasound & $\begin{array}{l}\text { - } \quad \text { Soundwaves (1 to } 10 \mathrm{MHz}) \text { to } \\
\text { visualise soft tissue } \\
\text { - Soundwaves are scattered } \\
\text { depending on tissue density } \\
\text { (echogenicity) } \\
\text { - } \quad \text { Hypo-echoic (darker pathology } \\
\text { image due to tumour being of } \\
\text { lighter density than } \\
\text { surrounding tissue) } \\
\text { - Hyper-echoic (brighter pathology } \\
\text { image due to tumour being of } \\
\text { greater density than } \\
\text { surrounding tissue) }\end{array}$ & $\begin{array}{ll}\text { - } & \text { Non-ionising radiation } \\
\text { - } & \text { Crosh resolution } \\
\text { - } & \text { anatomy representation } \\
\text { - } & \text { and accessible } \\
\text { Real time information }\end{array}$ & $\begin{array}{l}\text { - } \begin{array}{l}\text { Limited depth } \\
\text { (approximately } \\
10 \mathrm{~cm})\end{array} \\
\text { - } \\
\text { Operator dependent } \\
\text { Unable to detect } \\
\text { capillary network }\end{array}$ \\
\hline X-Ray CT & $\begin{array}{l}\text { - X-ray beams through the body } \\
\text { - Measures attenuation of x-ray due } \\
\text { to tissue density }\end{array}$ & $\begin{array}{ll}\text { - } & \text { Fast acquisition times } \\
\text { - } & \text { Greater sensitivity } \\
\text { - } & \text { 3-d image reconstruction }\end{array}$ & $\begin{array}{ll}- & \text { Ionising radiation } \\
\text { - } & \text { Requires contrast } \\
\text { media with high } \\
\text { atomic number }\end{array}$ \\
\hline MRI & 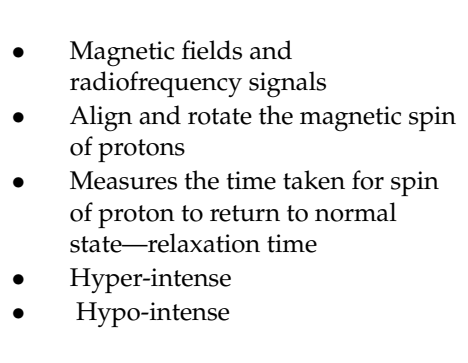 & $\begin{array}{ll}\text { - } & \text { Non-ionising radiation } \\
\text { - } & \text { Superior soft } \\
\text { tissue definition } \\
\text { - } \quad \text { Multiplanar reformation } \\
\text { Superior } \\
\text { spatial resolution }\end{array}$ & 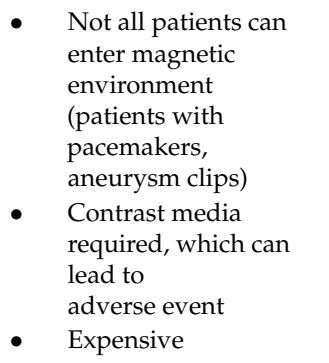 \\
\hline PET & $\begin{array}{l}\text { Visualization, characterisation and } \\
\text { quantification of metabolic } \\
\text { processes at cellular and sub } \\
\text { cellular level in body. } \\
\text { Positron emitting radioisotopes } \\
\text { provide pairs of gamma rays } \\
\text { (180 degrees to each other) with } \\
511 \text { KeV diagnostic energy, } \\
\text { identified with gamma camera. } \\
\text { Examples for diagnostic purposes } \\
\text { include fluorine-18, } \\
\text { gallium-68, copper-64. } \\
\text { An example of a theranostic } \\
\text { radioisotope is lutetium-177. } \\
\text { Radiolabelling of a variety of } \\
\text { markers and molecules: } \\
\text { - } \quad \text { FDG (glucose metabolism), } \\
\text { FLT (quantification of cell } \\
\text { proliferation), } \\
\text { FES (measure regional estrogen } \\
\text { binding), MISO (evaluate } \\
\text { tumour hypoxia). }\end{array}$ & $\begin{array}{l}\text { - Ideal tool for early } \\
\text { diagnosis and } \\
\text { targeted imaging. } \\
\text { Optimize gene and } \\
\text { drug therapy. } \\
\text { - Simultaneous monitoring } \\
\text { of molecular events } \\
\text { in body. }\end{array}$ & 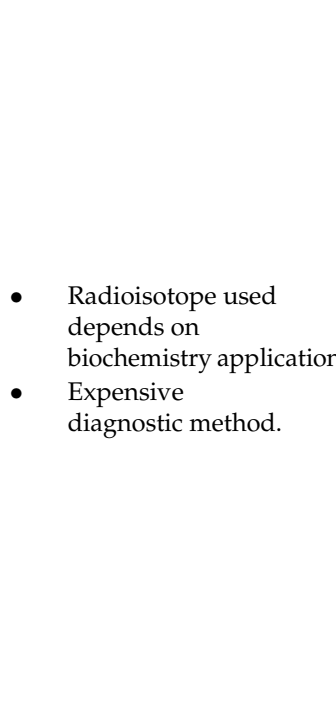 \\
\hline SPECT & $\begin{array}{l}\text { - } \begin{array}{l}\text { Direct imaging of photon energy } \\
\text { (gamma ray). }\end{array} \\
\text { - Utilizes single photons emitted by } \\
\text { gamma-emitting radioisotpes such } \\
\text { as technetium-99m, indium- } 111 \\
\text { and iodine- } 123 \text {. } \\
\text { - Spatial resolution clinical aspect } \\
8-12 \mathrm{~mm} \text {. }\end{array}$ & $\begin{array}{l}\text { Explains the function of, } \\
\text { and blood flow } \\
\text { to, organs. }\end{array}$ & $\begin{array}{l}\text { Longer } \\
\text { biological half-life. } \\
\text { Increased } \\
\text { probability of } \\
\text { detecting } \\
\text { secondary tumors. }\end{array}$ \\
\hline
\end{tabular}

The introduction of mammography nearly 40 years ago saw a reduction in mortality from breast cancer, although this technique provides only a localised view, and whole body scans are required to 
detect metastatic disease. Mammography can capably identify calcific lesions, however, determining if other identified lesions (by mammography) are benign or malignant can be difficult. Despite different imaging modalities, a large number of patients will also present with micrometastases, which are often missed, as micrometastases are undetectable by conventional techniques [2,4].

\section{Current Imaging Modalities and the Need for Personalized Imaging}

Currently, medical imaging modalities rely on the principle of signal-to-background ratio (SBR), or tumour-to-background ratio, to create contrast within an image when the energy is attenuated by different mechanisms: soundwaves, $x$-ray or electromagnetism with radio-frequency waves $[4,5]$. Accordingly, to detect tumours, the signal generated by the tumour must be greater than that of the background signal produced by the surrounding normal tissues [4]. In order to improve SBR, contrast agents relative to each modality can be used. Contrast agents enhance imaging and identify malignant cells by distinguishing pathological cells from normal tissues on the basis of different anatomical boundaries or pathophysiology $[5,13]$. Contrast agents alter how the signal or energy is demonstrated by pathology when used with ultrasound, CT or MRI, to enhance the visibility when compared to adjacent tissues [5]. However, despite the use of contrast agents to enhance diagnostic medical imaging, contrast agents can be fairly non-specific to the pathology or malignant cells [4]. For example, the contrast agent in MRI, gadolinium, can be used to detect brain metastases, infectious and inflammatory processes of brain diseases, as well as characterising mass lesions in the musculoskeletal system [14]. To assess tumour biology, PET has typically incorporated radiolabelled fluorodeoxyglucose (FDG) due to the increased glycolytic rate, the Warburg Effect, exhibited by the majority of malignant tumour cells [15]. PET imaging provides information on anatomical location of tumours by exploiting the increased metabolic rate of tumours [15] and the use of radiolabeled FDG readily explains this fundamental principle. Despite advances in PET, there are challenges in molecular imaging. A major factor in molecular PET imaging is that it relies on the uptake of FDG to measure glucose metabolism by pathological cells. While pathological cells have an increased uptake of FDG, physiological uptake by normal tissues or inflammatory cells such as macrophages are highly variable, and in some instances the accumulation cannot be predicted [16]. As FDG can accumulate in normal tissues or inflammatory cells, thus decreasing availability of tracer uptake by pathological tissue, this can also lead to false positive detection and misdiagnosis [16,17]. Furthermore, FDG uptake relies on malignant cells to be metabolically active. However, some tumour cells can enter a dormant state [18]. To improve the sensitivity of diagnostic imaging, agents are being developed to target malignant cells or their products, to enable molecular imaging of a tumour [4].

Further to $\left[{ }^{18} \mathrm{~F}\right] \mathrm{FDG}$, other ${ }^{18} \mathrm{~F}$-labeled tracers also play a vital role in imaging and understanding tumours. $\left[{ }^{18} \mathrm{~F}\right]-3^{\prime}$-fluoro-3'-deoxythymidine (FLT) is used for quantifying cellular proliferation [9], in particular tumour proliferation, without accumulating in inflammatory processes [19]. $\left[{ }^{18} \mathrm{~F}\right] \mathrm{FLT}$ can be incorporated into the patient management plan to monitor tumor biology response to treatment [19]. $\left[{ }^{18} \mathrm{~F}\right] \mathrm{FDG}$ and $\left[{ }^{18} \mathrm{~F}\right] \mathrm{FLT}$ have both been used to investigate TNBC, with mixed results. However, one study [20] evaluated response to neo-adjuvant chemotherapy in triple negative breast cancer same subject murine models with $\left[{ }^{18} \mathrm{~F}\right] \mathrm{FDG}$ and $\left[{ }^{18} \mathrm{~F}\right] \mathrm{FLT}$ and found comparable sensitivity. $\left[{ }^{18} \mathrm{~F}\right]$-fluoroestradiol (FES) can be used to measure estrogen binding in estrogen receptor (ER) positive breast cancer $[10,21,22]$ and identify the aggressiveness of endometrial tumors [23]. In their study, Venema et al. showed a strong correlation between $\left[{ }^{18} \mathrm{~F}\right]$-FES uptake and ER expression in their patient cohort and this was confirmed with tumor biopsy and staining diagnosis.

A number of ${ }^{18} \mathrm{~F}$-labeled compounds are being tested to accurately identify tumor hypoxia [11]. This is important, as tumor hypoxia is linked with resistance to radiotherapy and chemotherapy [24]. The original and commonly used hypoxic PET tracer is $\left[{ }^{18} \mathrm{~F}\right] \mathrm{FMISO}$, (fluoromisonidazole), however, it is known to be slow to accumulate at tumor sites. This was tested against second generation $\left[{ }^{18} \mathrm{~F}\right]$ fluoroazomycin arabinoside (FAZA) and third generation $\left[{ }^{18} \mathrm{~F}\right]$ flortanidazole (HX4) hypoxic PET tracers to determine optimal imaging time and compare their performance (tumor-to-background 
ratio) [11]. Uptake of $\left[{ }^{18} \mathrm{~F}\right] \mathrm{FMISO}$, indicating hypoxia, correlated with glioblastoma (GBM) tumor grade; whereby Grade IV GBM demonstrated higher uptake than lesser glioblastoma grades [12]. In their study cohort, longer survival times were recorded in patients with no uptake of $\left[{ }^{18} \mathrm{~F}\right] \mathrm{FMISO}$ compared to patients demonstrating $\left[{ }^{18} \mathrm{~F}\right] \mathrm{FMISO}$ uptake.

\subsection{Box 1}

Alpha particles are emitted from an atom's nucleus. They are relatively large subatomic particles that rapidly lose their energy to the material that they pass through. This feature makes them highly destructive to cells, and can lead to detrimental effects on all cells if delivered non-specifically. Alpha particles are known to travel up to $100 \mu \mathrm{m}$ in human tissue $[25,26]$ which is approximately equivalent to the dimension of 6 cells [25]. Targeted applications of alpha particle emitting nuclides are of growing interest if they can be correctly targeted to cancer sites. In this manner, they would have the advantage of eradicating cancer cells with their particle energy and minimizing radiation damage to nearby healthy cells. Clinical interest in alpha particle emitting nuclides include actinium-225 [6,25] for prostate cancer sufferers [27] and radium-223 with known skeletal uptake are used to treat certain bone cancers [6,25].

Compared to alpha particles, beta particles are smaller, negatively charged and travel at a faster speed. They are also emitted from an atomic nucleus, but they undergoes radioactive decay due to a high ratio of neutrons to protons. Beta particles have higher energy than alpha particles and thus have greater penetration ability. However, they can be less damaging to human cells because their ionization energy is dispersed over a greater area [28]. The most commonly used beta particle emitter used clinically is yttrium-90. It has the therapeutic advantage of treating either widespread oncology conditions such as lymphoma [29] and leukemia [30] as well as well as tumors engulfing large organs such as the liver [31,32] and pancreas [33].

Gamma rays are considered to be composed of pure energy with no mass, whereas alpha and beta particles are comprised of both mass and energy. Gamma rays have the highest energy levels of any ionizing radiation known to us in the electromagnetic spectrum and can easily pass directly through the human body. In fact, high density material such as lead or concrete is required to attenuate gamma rays [28,34]. The development of the gallium generator has introduced the widespread clinical use of gallium-68, which is now the most commonly used gamma ray emitter in Nuclear Medicine and used diagnostically with PET imaging (including PET/CT and PET/MRI). When gamma ray radiopharmaceuticles are internalized by a patient, their energy exits the patient and is detected by a gamma camera (PET camera or scintillation detector or Anger camera) [34,35].

For successful targeting of tumour sites within the human body, appropriate chelating agents are required to maintain stability between the radioactive material and the targeting modality, in vivo and in vitro [36]. Therefore, the choice of chelator used can be determined by the chemistry of both the targeting ligand and the radioactive material. Also of consideration is the behaviour or application required of the overall compound, either in vivo or in vitro [37,38]. Understanding the kinetic inertness of a chelating agent is regarded as a more reliable indicator for in vivo applications compared with its hemodynamic stability assessments [37]. In fact, chemistry experiments using a metal-exchange competition approach with biological material such as blood serum will provide directly relevant information for in vivo translation [37]. This will allow quantification of any trans-chelation that occurs from the radioactive material to serum proteins or enzymes.

\section{Personalised Imaging Techniques-Monoclonal Antibodies}

In comparison to current medical imaging modalities, molecular imaging has emerged to advance the field of medicine through the specificity, sensitivity and quantification of screening and early diagnosis of diseases [39]. Molecular imaging provides a non-invasive technique for the visualisation and characterisation of biological functions, molecular targets and cellular processes associated with in vivo [39]. The principle of molecular imaging relies on a highly specific probing molecule labelled 
with a radioisotope that binds to a specific receptor with high specificity and affinity, to enable external signal detection [40] (Figure 1). In order to determine the correct choice of appropriate target, typically protein expression data is required to inform selection. The use of biopsies and immunohistochemistry has provided an abundance of information in this respect. Monoclonal antibodies have long been used in diagnostic pathology to diagnose patients and find prognostic markers. Monoclonal antibodies have also been used as therapeutic agents, due to high affinity and binding to specific tumour surface antigens. For this reason, antibodies have also be repurposed and engineered to deliver radionuclide isotopes for molecular imaging [40-42]. With molecular imaging, antibodies are covalently linked to an imaging probe or a contrast agent to provide a signal after binding to the targeted tumour ligand, which can be detected by PET and combined with either CT or MRI to identify the anatomical location of the molecular activity $[43,44]$.

Thus, radioisotopes such as gallium-68 can be attached through a bifunctional chelating approach to generate "target-specific gallium radiopharmaceuticals" for molecular imaging [45]. This approach requires a bifunctional chelator, to bind to the radioisotope with high affinity at one end of the chelating complex, to enable stability in vivo, while at the opposite end of the complex, to bind to the targeting agent [45]. To improve the application of antibodies, the therapeutic and diagnostic potential of antibodies can be combined to implement theranostic treatments-simultaneous functions of molecular imaging and targeted therapy, depending on what radioisotope is attached [42] (See Section 2.1).
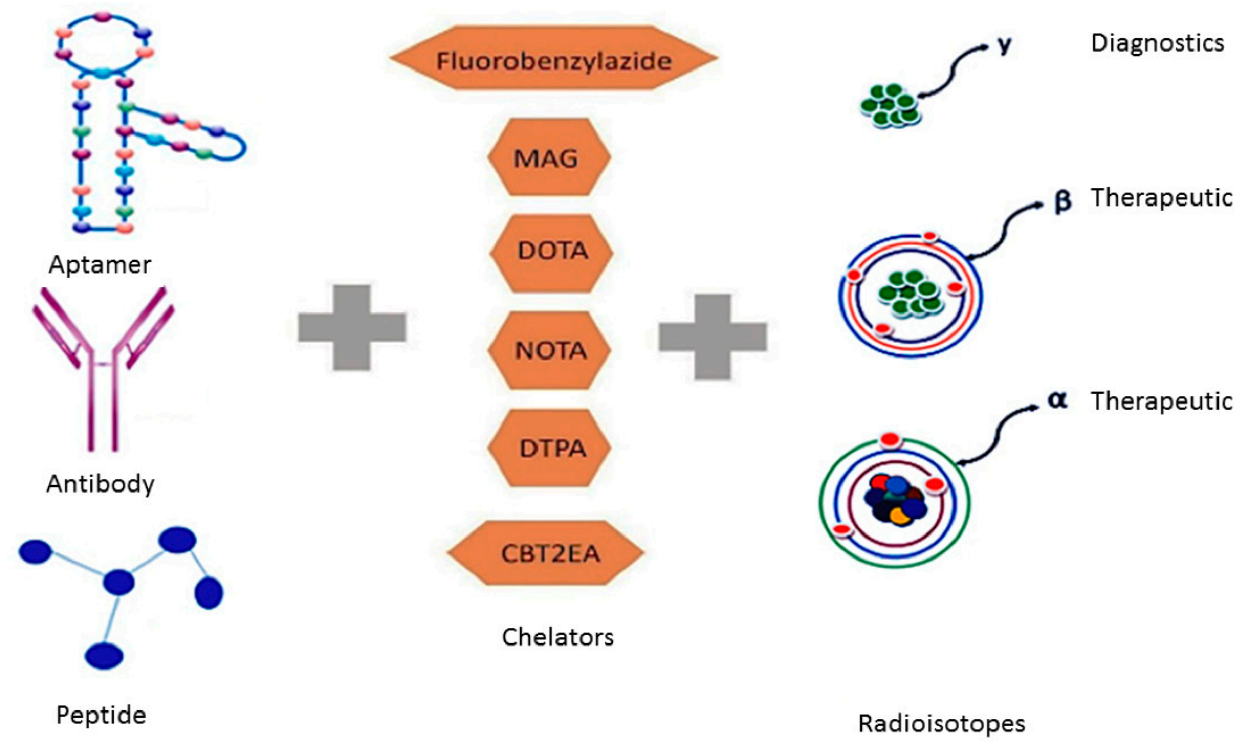

Figure 1. Targeting ligands are conjugated to a chelator which can bind a radioisotope that can be used for diagnostics or therapeutics.

Various clinical trials are under consideration with monoclonal antibody conjugates. $\left[{ }^{64} \mathrm{Cu}\right]-$ NOTA-YY146 is available for lung cancer diagnostics and has shown promising results along with CD146 binding. Large numbers of CD146 antigens are present on the cell surface in glioblastoma and gastric carcinoma, suggesting other potential opportunities for this antibody conjugate [46-48]. ${ }^{111}$ In-labelled 7E11 antibodies and ${ }^{123}$ I-labelled anti-PSMA antibody fragment scFvD2B (PSMA) demonstrated positive results but limited use with SPECT/CT and ${ }^{111}$ In-labelled j591 antibodies are available for prostate cancer diagnosis via prostate specific membrane antigen (PSMA) binding [49,50]. ${ }^{111}$ In-j591 is available for SPECT scanning, with detection limited to antibody mass dependency. However, this antibody also demonstrated nonspecific binding to the non-prostate cancer sites, and took 5-7 days to appear in the blood stream as well as penetrate the tumor, thus making imaging quite difficult to manage [51]. In comparison $\left[{ }^{177} \mathrm{Lu}\right]-\mathrm{PSMA}-617$ and $\left[{ }^{68} \mathrm{Ga}\right]-\mathrm{PSMA}-617$ displayed better characteristics in phase 3 clinical trials without any major side effects [52]. 
Clinical studies have also been performed with $\left[{ }^{64} \mathrm{Cu}\right]$-DOTA-trastuzumab as a theranostic tool in breast cancer (HER2+ and HER2-). Twenty four hours post injection, the conjugate appeared to have bound to HER2, and PET was able to produce images which demonstrated a good uptake in HER2+ cases. With copper-64 having a half-life of $13 \mathrm{~h}$, the optimal imaging time window would be at this time point, when the initial blood stream concentration had reduced [53]. Another study also highlighted that $\left[{ }^{64} \mathrm{Cu}\right]$-DOTA-trastuzumab conjugate saved patients from invasive biopsy procedures [54]. Zirconium- 89 has also been used as a radiolabelled conjugate for metastatic breast carcinoma and exhibited promising results due to its half-life (3.3 days). This long half-life allowed for a long blood circulation time and produced better quality diagnostic images in early metastatic breast cancer [55-57]. It should be noted, however, that while trastuzumab binds to HER2, there was also uptake in the HER2 - patients which could be due to the enhanced permeability and retention effect in solid tumours.

Radiolabelled antibodies are also being tested to treat breast cancer and other carcinomas. Radiolabelled monoclonal antibodies used to treat breast carcinoma ideally should be designed to bind to tumor cells and be excreted from the body following their cytotoxic effects. However, the antibodies bind to their site longer than required, thus causing bone toxicity and increasing the risk of diffusion in healthy organs instead of tumor cells $[58,59]$. Moreover, adding DTPA or DOTA cages in radiolabelling usually diminishes radioactivity of mAbs conjugates, either because of iodination of tyrosine or addition of metal chelators [60,61]. $\left[{ }^{177} \mathrm{Lu}\right]-\mathrm{DTPA}-$ Trastuzumab has been developed, but due to toxicity issues, other methods of antibody radiolabelling are under consideration [62]. A newly developed antibody PAN-622 radiolabelled with ${ }^{111}$ In-conjugate, [ $\left.{ }^{111} \mathrm{In}\right]-\mathrm{DTPA}-\mathrm{PAN}-622$, has shown promising results in clinical trials. $\left[{ }^{213} \mathrm{Bi}\right]$-DTPA-PAN-622 to HAAH has demonstrated a promising approach in a pilot therapy study of a primary tumor. Researchers are hopeful that PAN-622 mAbs will be a good theranostic tool for metastatic breast cancer [63]. [177 Lu]-DOTA-F(ab')2-trastuzumab was developed to overcome clearance issues, low tumor/blood and normal/tumor tissue. This conjugate shows promising stability in human serum under physiological condition and due to emission of alpha particles and gamma rays, has the potential to be used as a theranostic tool [64]. At the moment, however, only two FDA approved radiolabelled antibodies are available: ${ }^{131}$ I-tositumomab Bexxar ${ }^{\circledR}$ (tositumomag radiolabeled with iodine-131) and Zevalin (incorporating yttrium-90) for the treatment of non-Hodgkin lymphoma and advance follicular lymphoma, [65].

Although antibodies have improved diagnostic molecular imaging and have potential to change therapeutic options, there are challenges that remain. There are several possible problems with radiolabelled antibody compounds. Firstly, tissue uptake can be reduced by covering the receptor site from free antibodies or non-specific antibodies. Secondly, cross reactivity of mAbs can cause toxicity; explained by non-specific binding of $\mathrm{mAb}$ radiolabel conjugate to the receptor sites. Thirdly, mAbs function could be damaged due to structural modification. Fourth, allergic reactions can occur (even after administration of a test dose) [66-68]. As well, with doses lower than therapeutic levels, antibodies as an imaging agent still have the potential to interfere with biological functions and illicit immunological reactions in patients [43]. Thus, an important criteria to consider when developing a novel imaging agent is for it to be biologically inert, so that it does not interfere with biological functions leading to potential safety concerns [40]. While antibody-based molecular imaging provides evidence for proof of concept that targeting cell surface or tumour biomarkers is effective, there is a need for imaging agents that have better properties.

\section{Personlised Imaging Techniques-Peptides and Peptidomimetics}

Peptides are short organic polymers. Amino acids are conjugated to each other and form a bond between multiple amino acids called peptides. Peptides may possess their own biological function or be a structural and functional part of protein molecule. Artificial peptides are also available with covalent bond between amino acid molecules [69]. Peptides are produced relatively easier than mAbs, are quicker to penetrate tumor sites and are rapidly excreted from the body [70,71]. Peptides can 
be used for the delivery of cytotoxic drugs and radioisotopes, as well as vaccines and hormones. Radiolabelled peptide conjugates are comprised of three parts: peptides, chelator, radioisotopes. In the late 1980's, the first radiolabelled peptide was the Somatostatin mimic [ ${ }^{111}$ In]In DTPA-octreotide (Octreoscan), which was introduced as a gold standard diagnostic approach. Today, Octreoscan and NeoTect, ${ }^{99}$ Tc-depreotide, are the only FDA approved radiotracers available commercially. Neo Tect is commonly used for lung cancer imaging and Octreoscan is used for neuroendocrine tumors [72-74]. [111 In]In DTPA-octreotide has a short half-life following administration into the body and may not be able to produce desired effects. As a result, the next generation of radio-peptide therapies utilized $\left[{ }^{90} \mathrm{Y}\right] \mathrm{Y}$-DOTA-Tyr ${ }^{3}$-octreotide and has demonstrated more stable binding between radioisotope and chelator and demonstrated superiority in treating gastroenteropancreatic neuroendocrine tumours (GEPNETs). Also a new generation of radiolabelled peptide, $\left.\left[{ }^{[77} \mathrm{Lu}\right]\right] \mathrm{Lu}$ DOTA,Tyr ${ }^{3}$-octreotate, has been introduced, improving somatostatin receptor binding affinity from six to nine fold. The use of lutetium-177 with this peptide not only provides diagnostic ability but also therapeutic effects [75]. Appropriate selection of peptide according to cell surface expression, attached to a suitable chelating agent, could develop innovative diagnostic or theranostic probes [76]. CXCR4 expression in lymph proliferative disease has been studied by using $\left[{ }^{68} \mathrm{Ga}\right] \mathrm{Ga}$-pentixafor with PET imaging and compared with $\left[{ }^{18} \mathrm{~F}\right] \mathrm{FDG}$. Both tracers show uptake in lymphoma lesions. PET/MRI demonstrated the $\left[{ }^{68} \mathrm{Ga}\right]$-pentixafor peptide conjugate was highly specific to tumor lesions compared to $\left[{ }^{18} \mathrm{~F}\right] \mathrm{FDG}$. Superior lesion characteristics were also demonstrated in multiple myeloma patients. $\left[{ }^{68} \mathrm{Ga}\right]-$ pentixafor-PET/MR exhibited a high contrast between the bone marrow and the lymphoma lesions [77].

Common difficulties of using peptides as a drug delivery carrier are limited stability due to proteolysis by peptidases, poor transport properties through cell membranes, low oral bioavailability, rapid excretion, and poor target specificity resulting from the flexible nature of peptides. In contrast, peptidomimetics (also called peptide mimics), can be designed by the modification of an existing peptides or artificial introduction of alpha and beta amino acids in peptide structures. Peptidomimetics have fewer cross target interactions, better transport properties through biological membranes, resistance to immune responses and improved resistance to degradation by peptidases [78,79]. $\left[{ }^{68} \mathrm{Ga}\right] \mathrm{Ga}-N O D A G A-T H E R A N O S T^{\mathrm{TM}}$ is a $\alpha \mathrm{v} \beta 3$ integrin antagonist first used in humans for lung and breast cancer diagnosis. Two patients were imaged and treated with $\left[{ }^{68} \mathrm{Ga}\right] \mathrm{Ga}-N O D A G A-$ THERANOST $^{\mathrm{TM}}$, the first patient (28 year old female with grade three HER2+ breast cancer and liver metastases) received $472 \mathrm{MBq}$ of radiolabelled peptidomimetics conjugate and highlighted 25 lesions; however, in this same patient, $\left[{ }^{18} \mathrm{~F}\right] \mathrm{F}-\mathrm{FDG}$ was only able to highlight 12 positive lesions. The second patient (61-year-old male with neuroendocrine neoplasm of the right lower lobe of the lung) received $496 \mathrm{MBq}$ of $\left[{ }^{68} \mathrm{Ga}\right] \mathrm{Ga}-N O D A G A-T H E R A N O S T^{\mathrm{TM}}$ which demonstrated $\alpha \mathrm{v} \beta 3$ receptor expression and angiogenesis. $\left[{ }^{68} \mathrm{Ga}\right]$ Ga-NODAGA-THERANOST ${ }^{\mathrm{TM}}$ revealed high uptake, specificity and sensitivity in tumors and metastatic sites $60 \mathrm{~min}$ post injection [80]. A clinical trial is currently in progress with 120 participants with an estimated completion date in 2020 and the results may provide compelling evidence for further investigation of petidomimetics [81]. Several peptidomimetics have been developed to PSMA for both diagnostic ( $\left[{ }^{68} \mathrm{Ga}\right]$ PSMA-11, and $\left[{ }^{18}\right.$ F]PSMA-1007 $\left.[82,83]\right)$ and therapeutic ([ $\left.{ }^{177} \mathrm{Lu}\right]$ PSMA-617 [84]) applications. These have demonstrated promising results in clinical trials though these trials have been small to date $[85,86]$. The results from a single arm phase II clinical trial of $\left[{ }^{177} \mathrm{Lu}\right]-\mathrm{PSMA}-617$ demonstrated high response rates though most patients did experience adverse events during the trial, predominantly grade 1 and 2 xerostomia, also known as dry mouth [87]. The results do support the need for a randomized control trial to further assess the efficacy compared to current standards of care. However, major limitations with peptidomimetics include disruption of multiple protein-protein interaction (PPI) sites and this may be the case where similar homology exists, also increasing the chances of toxicity due to off-target effects, as well as their poor serum stability [88-91]. 


\section{Personalised Imaging Techniques-Aptamers}

Aptamers, also known as "chemical antibodies", are short (20-100 bases) single-stranded RNA (ssRNA) or DNA (ssDNA) oligonucleotides that bind to targets with high affinity and selectivity [92,93]. Aptamers have the ability to fold into three dimensional structures and bind to their target in a similar manner to their antibody protein counterpart via shape recognition [94]. Aptamers are generated by "Systematic Evolution of Ligands by Exponential enrichment" (SELEX) [95]. This process involves iterative rounds of incubation, isolation, elution and amplification of a randomised oligonucleotide library to a target to produce aptamers with high selectivity and specificity to the target $[96,97]$. Aptamers generated by SELEX demonstrates high affinity and specificity to a target, as the nucleic acids undergo iterative rounds of incubation, washing, isolation and amplification [96]. The initial library, consisting of random RNA and DNA molecules are incubated with a target of interest, biomarkers, proteins or even whole cells. Following incubation, unbound sequences are washed away to isolate and separate the bound sequences. To generate an enriched pool of sequences, the bound sequences are then eluted from the target and amplified using polymerase chain reaction (PCR) (reverse transcription PCR for RNA-based) [98]. This enriched pool of sequences then undergoes iterative rounds of selection-amplification cycles, to increase the affinity of the aptamers, as each consecutive round will decrease the heterogenicity of the pool [98]. Following analysis of binding affinities, the pool with the best affinity and specificity is then cloned and sequenced, or subjected to next generation sequencing, and further characterized to ensure specificity and sensitivity.

In comparison, aptamers hold many advantages over antibodies (Table 2). Unlike antibodies which cannot regain function after being denatured, aptamers are more stable and resistant to changes in $\mathrm{pH}$ and temperature, which also enables them to be easily chemically modified [99]. Antibodies require in vitro or in vivo production which can increase variation between batches, whereas this variation is reduced in aptamers as they are synthesized chemically [99]. Due to their nucleic acid composition, aptamers are generally non-immunogenic and non-toxic [92,93]. Lastly, an important advantage of aptamers is their size $(5-15 \mathrm{kDa})$ in comparison to large monoclonal antibodies (approximately $150 \mathrm{kDa}$ ) [100]. As aptamers are much smaller than antibodies, aptamers have superior tissue penetration (greater capabilities to be internalised by tumours) $[99,101]$. Furthermore, the smaller size of aptamers also enables them to bind hidden epitopes which cannot be accessed by the larger antibodies [98]. Thus, given the numerous desirable properties exhibited by aptamers, the development of aptamers as molecular imaging probes is more promising than antibodies in diagnostic imaging.

Table 2. Comparison of antibodies versus aptamers (adapted from [102]).

\begin{tabular}{ccc}
\hline Property & Antibodies & Aptamers \\
\hline Reproducibility & Batch-to-batch variation & No batch-to-batch variation \\
Cost & Can be expensive to generate & Generally cheaper to generate \\
Generation time & Can be cross reactive & Can be rapid \\
Specificity & Slow & High specificity \\
Tumour penetration & Rapid \\
Stability & Sensitive to pH and temperature & Stabile in range of pHs and temperatures \\
\hline
\end{tabular}

The versatility of aptamers enables the radiolabelling techniques used for targeting moieties such as antibodies, peptides or proteins, to be transferred to the aptamers with ease [98]. Coupled with the ability of aptamers to be generated and selected for against a plethora of targets with high specificity, affinity, and no toxicity, aptamers emerge as proficient radiopharmaceuticals in oncology (Table 3). The first radiolabelled aptamer was developed in 2006, TTA1 (extracellular matrix protein tenascin with fluorescent and technetium-99m tag). Aptamer uptake is dependent on the presence of human tenascin-C protein, which exists in solid tumors such as breast, colon, lung and glioblastoma. Radiolabelled aptamers have been observed in glioblastoma (U251) and breast cancer (MDA-MB-435) xenograft models on planar scintigraphy. Intravenous administration of [ $\left.{ }^{99 \mathrm{~m}} \mathrm{Tc}\right]-\mathrm{TTA} 1$ aptamer was also observed in mice at different time intervals in biodistribution and imaging studies, with signal 
first observed at $10 \mathrm{~min}$ and at $3 \mathrm{~h}$ complete tumor diffusion was observed as well as renal and hepatic clearance. Rapid tumor uptake, high renal clearance rate to target specific binding sites and ideal conjugation of aptamer with tumors raised the importance of aptamers to be used as a theranostic tool [103]. $\left.{ }^{99} \mathrm{Tc}\right]-T T A 1$ in murine studies highlighted the importance of aptamer as diagnostic probes. In another study that investigated the use of technetium- $99 \mathrm{~m}$ conjugated to an aptamer that binds to the MUC1 receptor, which is highly expressed in various cancers such as lung, breast and prostate, a good tumour-blood ratio was observed at $16 \mathrm{~h}[99,104]$. However, further work is required to turn this into an efficient diagnostic probe.

Table 3. Examples of radiolabelled aptamers.

\begin{tabular}{|c|c|c|c|c|c|}
\hline Radioisotopes & Chelator & Aptamer & Target & Application & References \\
\hline $\begin{array}{c}{ }^{99 \mathrm{~m}} \mathrm{Tc} \\
\text { technetium-99m }\end{array}$ & N/A & TTA1 & MUC1 receptor & $\begin{array}{l}\text { Breast, lung colon and } \\
\text { glioblastoma }\end{array}$ & [103] \\
\hline $\begin{array}{c}{ }^{99 \mathrm{~m}} \mathrm{Tc} \\
\text { technetium-99m }\end{array}$ & MAG & F3B-aptamer & hMMP-9 & Malignant melanoma & [105] \\
\hline $\begin{array}{c}{ }^{99 \mathrm{~m}} \mathrm{Tc} \\
\text { technetium-99m }\end{array}$ & DOTA & F3B-aptamer & hMMP-9 & Malignant melanoma & [106] \\
\hline $\begin{array}{c}{ }^{111} \mathrm{In} \\
\text { indium-111 }\end{array}$ & DOTA & F3B-aptamer & hMMP-9 & Malignant melanoma & [105] \\
\hline $\begin{array}{l}{ }^{64} \mathrm{Cu} \\
\text { copper-64 }\end{array}$ & DOTA & AS1411 & $\begin{array}{l}\text { Large nucleolin } \\
\text { complex }\end{array}$ & Lung cancer & [107] \\
\hline $\begin{array}{c}{ }^{64} \mathrm{Cu} \\
\text { copper-64 }\end{array}$ & NOTA-Bn & AS1411 & $\begin{array}{l}\text { Large nucleolin } \\
\text { complex }\end{array}$ & Lung cancer & [108] \\
\hline $\begin{array}{c}{ }^{64} \mathrm{Cu} \\
\text { copper-64 }\end{array}$ & CB-TE2A & AS1411 & $\begin{array}{l}\text { Large nucleolin } \\
\text { complex }\end{array}$ & Lung cancer & [108] \\
\hline $\begin{array}{l}{ }^{18} \mathrm{~F} \\
\text { fluorine-18 }\end{array}$ & Fluorobenzylazide & Heraptamer-1 & $\begin{array}{l}\text { HER2 over } \\
\text { expression }\end{array}$ & HER2 + cancer & [109] \\
\hline $\begin{array}{l}{ }^{18} \mathrm{~F} \\
\text { fluorine-18 }\end{array}$ & Fluorobenzylazide & Heraptamer-2 & $\begin{array}{l}\text { HER2 over } \\
\text { expression }\end{array}$ & HER2+ cancer & [109] \\
\hline
\end{tabular}

Conjugation of aptamers with a chelating agent is considered an important chemistry step, as it provides in vitro and in vivo stability. There have been a number of aptamers tested with DOTA, NOTA, $\mathrm{MAG}_{3}$ and DTPA chelators. ${ }^{99 \mathrm{~m}} \mathrm{Tc}_{\mathrm{C}}-\mathrm{MAG}_{3}$ (Technetium-99m) $\left[{ }^{99 \mathrm{~m}} \mathrm{Tc}\right]$ mertiatide $\left(\mathrm{MAG}_{3}\right)$ has been used for analysing kidney function with nuclear medicine imaging. [ $\left.{ }^{99 \mathrm{~m}} \mathrm{Tc}\right]-\mathrm{MAG}_{3}$ forms a stable chelate and can act as a bifunctional chelator, in biological radiolabelling but due to complicated conjugate properties and radiolabelling chemistry, yield has always appeared low in comparison to the expected yield. Researchers highlight the cause of low yield, which was not only incomplete chemistry conjugation and purification of radiolabelled aptamer conjugates, but also due to labelling of impurities. Preliminary purification before labelling and use of rhenium-188 has been suggested to resolve this issue [38]. Thus a purified form of radiolabelling could achieve better results. In this study researchers used [ $\left.{ }^{99 \mathrm{~m}} \mathrm{Tc}\right]-\mathrm{MAG}_{3}-\mathrm{F} 3 \mathrm{~B}$ aptamer with high radiochemical purity and yield against hMMP-9 in melanoma. Quantitative biodistribution was assessed at different intervals, with 1.8\% $\mathrm{ID} / \mathrm{g}$ observed in the tumour at $1 \mathrm{~h}$, which was maximum uptake of the conjugate. However, a large amount of digestive tract accumulation and retention was observed (18\% ID/g at $1 \mathrm{~h})$, suggested to be due to lipophilic nature of the radiolabelled compound. Therefore, [ $\left.{ }^{99 \mathrm{~m}} \mathrm{Tc}\right]-\mathrm{MAG}_{3}$-aptamer conjugate would be difficult to use for determining digestive and abdominal region [105]. It is likely that this accumulation would prevent detection of metastases in this area, as well as in others due to the decreased bioavailability and thus precludes the use of this chelator for future studies.

$\left[{ }^{64} \mathrm{Cu}\right]-\mathrm{DOTA}-\mathrm{AS} 1411,\left[{ }^{64} \mathrm{Cu}\right]-\mathrm{NOTA}-\mathrm{Bn}-\mathrm{AS} 1411$ and $\left[{ }^{64} \mathrm{Cu}\right]-\mathrm{CB}-\mathrm{TE} 2 \mathrm{~A}-\mathrm{AS} 1411$ were developed for lung cancer diagnosis and are currently in animal trials. Non-small lung cancer cells were implanted in right and left thighs of BALB/c nu/nu female mice and after two weeks, when tumor growth was at $0.5-1.0 \mathrm{~cm}^{3}$, PET/CT were performed. Approximately, $7.4 \mathrm{MBq}(200 \mathrm{uCi})$ were injected via tail vein. Anesthetized mice were then scanned at 1, 3, 6 and $24 \mathrm{~h}$ after injection. The percentage injected dose per gram were used to calculate radioactivity, however, chelator-AS1411 yield were $86 \%+/-7 \%$ for DOTA, DOTA-Bn, NOTA-Bn and 78\% $+/-10 \%$ for CB-TE2A. The radiolabeling 
yield and specific activities were $65 \pm 15,57 \pm 19,15 \pm 6,75 \pm 24 \%$, and $45 \pm 26,48 \pm 16$, $2 \pm 1,9 \pm 4 \mathrm{mCi} / \mu \mathrm{mol}$ for $\left[{ }^{64} \mathrm{Cu}\right]-D O T A-A S 1411,\left[{ }^{64} \mathrm{Cu}\right]-C B-T E 2 A-A S 1411,\left[{ }^{64} \mathrm{Cu}\right]-D O T A-B n-A S 1411$ and $\left[{ }^{64} \mathrm{Cu}\right]-N O T A-B n-A S 1411$, respectively. Percentage uptake was affected by the chelator used. Copper-64 $\left[{ }^{64} \mathrm{Cu}\right]$-DOTA-AS1411 uptake increases dramatically in the first $6 \mathrm{~h}$ and at the 12 th $\mathrm{h}$ reached a stable phase and commenced clearing from the body in $48 \mathrm{~h}$. Copper-64 $\left[{ }^{64} \mathrm{Cu}\right]-\mathrm{CB}-\mathrm{TE} 2 \mathrm{~A}-\mathrm{AS} 1411$ demonstrated peak reach at blood plasma level concentration at $3 \mathrm{~h}$ with a lag phase at $9 \mathrm{~h}$ and no significant clearance in $48 \mathrm{~h}$. This data demonstrated that while CB-TE2A may have better properties for radiolabelling yield, the fact that it was not being cleared from the body at $48 \mathrm{~h}$ would lead to a low tumour-background ratio and thus, missed metastases.

In a different study, Li et al. radiolabelled AS1411 aptamer with ${ }^{64} \mathrm{Cu}$, and further explored the effects of four different bifunctional chelators; DOTA, CB-TE2A, DOTA-Bn and NOTA-Bn, on the pharmacokinetics of the aptamers in targeting lung cancer. In vivo results demonstrated high binding affinity to targeted cells and sufficient tumour uptake in $\mathrm{H} 460$ tumour bearing mice models, with ${ }^{64} \mathrm{Cu}$-CB-TE2A chelated being the most efficient [108]. In comparison to both, $\left[{ }^{64} \mathrm{Cu}\right]-\mathrm{NOTA}-\mathrm{Bn}-\mathrm{AS} 1411$ showed least uptake and proved an effective radiolabeling chelator. In further in vivo studies $\left[{ }^{64} \mathrm{Cu}\right]-\mathrm{CB}-\mathrm{TE} 2 \mathrm{~A}-\mathrm{AS} 1411$ showed better pharmacokinetic results and low liver uptake in comparison to $\left[{ }^{64} \mathrm{Cu}\right]$-DOTA-AS1411. [ ${ }^{64} \mathrm{Cu}$ ]-DOTA-AS1411 could not detect lung tumor with micro PET imaging. In addition to that, in vivo biodistribution were performed after each micro PET/CT scan at $24 \mathrm{~h}$ post injection. All major organs such as spleen, liver, kidney, heart and lungs showed reduction in accumulated radioactivity over $90 \%$ in comparison to $\left[{ }^{64} \mathrm{Cu}\right.$-DOTA-AS1411. However, tumor uptake reduced by one half $\left(1.17 \pm 0.04 \% \mathrm{ID} / \mathrm{g}\right.$ for $\left[{ }^{64} \mathrm{Cu}\right.$-DOTA-AS1411 vs $0.56 \pm 0.37 \% \mathrm{ID} / \mathrm{g}$ for $\left[{ }^{64} \mathrm{Cu}\right]$-CB-TE2A-AS1411). $\left[{ }^{64} \mathrm{Cu}\right]-\mathrm{CB}-\mathrm{TE} 2 \mathrm{~A}-\mathrm{AS} 1411$ express excellent in vivo kinetic stability with faster clearance and higher tumor-to-background ratio at $24 \mathrm{~h}$ post injection. Tumor-to-blood and tumor-to-muscle ratio for $\left[{ }^{64} \mathrm{Cu}\right]-\mathrm{CB}-\mathrm{TE} 2 \mathrm{~A}-\mathrm{AS} 1411$ were higher than $\left[{ }^{64} \mathrm{Cu}\right]-\mathrm{DOTA}-\mathrm{AS} 1411$ [108]. The anomaly being that even though high levels of chelation were achieved, tumor uptake may not be at the level desired. These studies indicate that the choice of chelator is important when considering the development of radioactive ligands for both targeted imaging and therapeutics.

$\left[{ }^{18} \mathrm{~F}\right]$ fluorobenzyl azide-Heraptamer- 1 and $\left[{ }^{18} \mathrm{~F}\right]$ fluorobenzyl azide-Heraptamer-2 conjugates have been developed for HER2 cancer and in vitro studies were performed with HER2 extracellular domain, using the HER2 positive SKOV3 cell line and the HER2 negative MDA-MB-231 cell line. Different concentration of heraptamers were prepared, incubated with HER2+ and HER2 - cell lines, then analysed by flow cytometry. Both aptamers show strong fluorescent signals with the positive cell line and no binding with the negative cell line. Results were obtained at low nanomolar concentration suggesting specificity and strong binding affinity of heraptamers. Also, no cytotoxicity was observed with SKOV3 cell line following 2 days of treatment. Following in vitro studies, direct radiolabelling of aptamers were used in PET imaging of mice. The conjugate was injected intravenously in a xenograft mouse model followed by PET scan at $30 \mathrm{~min}$ of post injection. Results varied from the in vitro studies with SKOV3 cell line. $\left[{ }^{18} \mathrm{~F}\right]$-heraptamers rapidly cleared from the renal route and demonstrated high uptake in bladder and kidneys. The gallbladder also showed high uptake due to metabolism of aptamer. Further studies performed in tumor bearing mice with ovarian cancer (SKOV3) demonstrated heraptamer-1 at $15 \mathrm{~min}$ post injection $(1.04 \pm 0.18 \% \mathrm{ID} / \mathrm{g})$ and heraptamer-2 $(0.67 \pm 0.10 \% \mathrm{ID} / \mathrm{g})$ uptake; at $1 \mathrm{~h}$ of post injection heraptamer- 1 decreased $(0.52 \pm 0.04 \% \mathrm{ID} / \mathrm{g})$ and heraptamer-2 $(0.41 \pm$ $0.14 \% \mathrm{ID} / \mathrm{g}$ ), representing reduced uptake at tumor sites. At $1.5 \mathrm{~h}$, organs were collected and analyzed for biodistribution of radiolabelled aptamers. High background signal properties (tumor-to-blood ratio) was observed, which represented an ideal approach for diagnostic purposes and resolved all uptake and degradation issues. Due to successful pre-clinical trials, this gives hope that these aptamers may provide future diagnostic purposes [109].

Conjugation of different molecules to aptamers enables their functionality to be modified accordingly. For example, Wang and Farokhzad [99] conjugated the A10 aptamer, targeted against Prostate-specific membrane antigen (PSMA) on prostate cancer cells, to superparamagnetic iron oxide 
nanoparticles (SPIONs). While the A10-SPION conjugate demonstrated high sensitivity and specificity for MRI detection at the targeted location, the study also showed that the resulting construct was capable of carrying and delivering a chemotherapeutic drug, doxorubicin, to the PMSA on prostate cancer cells [99]. Furthermore, recent studies with $\left[{ }^{177} \mathrm{Lu}\right]-P S M A$ labelled peptides, demonstrated the theranostic capabilities of the lutetium- 177 due to its ability to emit beta and gamma radiation simultaneously [110]. The beta-radiation is capable of destroying small tumours, due to maximal tissue penetration of $2 \mathrm{~mm}$, while gamma-radiation enables PET imaging of the tumour [110]. With the ease of conjugating aptamers, radiolabelling it with lutetium-177 radioisotope offers promising and novel theranostic capabilities.

The epithelial cell adhesion molecule, EpCAM, was one of the first cell surface markers to be associated with cancer [102] and has been associated with a poor prognosis in a number of different cancer subtypes [111,112]. EpCAM is a type I transmembrane glycoprotein highly expressed in epithelial cancers. In normal cells, EpCAM is localized to the basolateral membrane, but during cancer progression, the expression pattern changes to an intense uniform over-expression [113]. As EpCAM is over-expressed in epithelial cancers, it was thought to be a good target for directed therapies. However, to date, this has not been realized for a number of reasons. While it is over-expressed in cancer cells, it is also expressed in normal tissues. The first targeted therapies to EpCAM had a high affinity for their target and were unfortunately poorly tolerated by patients. This was theorized to be because the high affinity meant that the antibodies were binding to all EpCAM expressing cells, not just the highly expressing cancer cells. The next antibody that was generated therefore was engineered with a lower binding affinity to EpCAM. This was texted in patients with metastatic breast cancer and did show some efficacy. However, this efficacy was demonstrated only in patients that had a high expression of EpCAM on the cancer cells surface [114]. Given that there are few markers to utilize for targeted therapeutics for triple negative breast cancer and that EpCAM is present in close to $64 \%$ of these patients' tumours [115], it may represent a viable target for targeted medical imaging. A recent review article highlighted the issue of using antibodies against EpCAM but has highlighted the potential for using aptamers as targeted therapeutic delivery agents [102]. As detailed below, these aptamers are in the early stage of clinical development but have shown promise so far. As well, given the increased interest in radiolabelling aptamers as a viable alternative to antibodies, these may increase our diagnostic and theranostic capabilities for cancer patients, including patients diagnosed with triple negative breast cancer given there are no available targeted therapies to date.

A study by Xiang, et al. [101] demonstrated the superiority of EpCAM aptamers compared to monoclonal EpCAM antibodies in molecular imaging in vivo using xenograft mouse models. In this study, the EpCAM-targeting aptamer was conjugated to a DY647 fluorophore and injected intravenously into the tumour bearing mice. The aptamers demonstrated greater tumour penetration, accumulation and retention for molecular imaging, compared to antibodies, as they can increase the signal strength to be detected by the imaging scanners [101,116]. This aptamer, generated by Shigdar and colleagues, is a highly specific RNA aptamer used to target EpCAM. The specificity and binding affinity of the RNA aptamer was assessed against live human cancer cell lines expressing EpCAM and those that did not express EpCAM (breast, colorectal and gastric cancers) and analysed using flow cytometry. These modified RNA aptamers also demonstrated good bioavailability though DNA aptamers are less costly to work with [92]. Alshaer et al. developed a DNA aptamer, Ep1, and and demonstrated the generated Ep1 aptamer's ability to bind specifically and selectively to the EpCAM protein. The binding affinity and selectivity of the Ep1 aptamer was analysed using an EpCAM-positive gastric cancer cell line, KATO III, and comparing it to an EpCAM-negative mouse fibroblast, NIH/3T3 cells. The study showed greater aptamer-EpCAM interaction for the Ep1 and KATO III cell line, when analysed by flow cytometry and immunofluorescent assays [117]. Additionally, Song, et al. [118] have previously developed a 48 nucleotide DNA aptamer, SYL3C, which consists of three hairpin loops, targeting the EpCAM biomarker and demonstrated strong binding affinity and selectivity, using the MDA-MB-231 breast cancer cell line and KATO III gastric cancer cell line. Interestingly, Song et al. 
were able to also demonstrate the SYL3C aptamer's specificity by targeting the EpCAM biomarker on cancer cells in a mixed cell media. To further enhance sensitivity and specificity, the SYL3C aptamer was truncated by Macdonald, et al. [119], into three separate hairpins, EpA (nucleotides 5-21), EpB (nucleotides 22-37) and EpC (nucleotides 39-46). All three truncated aptamers demonstrated greater sensitivity in binding to EpCAM positive cell lines, HT29 (high level of EpCAM expression), and HEY (low level of EpCAM expression), when compared to the full length SYL3C aptamer. This study found that the truncation may have affected the 3-D conformational structure of both $\mathrm{EpB}$ and $\mathrm{EpC}$, as they were able to bind to a high EpCAM targets (HT29) with high affinity but could not completely interact with lower levels of EpCAM (HEY), when compared to EpA which had greater affinity with the HEY cell line. The aptamers generated are highly specific to targeting the EpCAM biomarker on cancer cells, as a result, this suggests the promising applications of utilising aptamers as in vivo molecular imaging agents.

While much has been done to both diagnose and treat systemic tumours, one of the areas of research lacking in any success to date has been the diagnosis and treatment of brain metastases. The numbers of brain metastases are increasing on a yearly basis though, because of the blood brain barrier (BBB), they are difficult to treat. Additionally, there are few techniques available to adequately diagnose small brain metastases. Both $\left[{ }^{18} \mathrm{~F}\right] \mathrm{FDG}$ PET and MRI have been used to diagnose brain metastases with varying accuracy. It has been demonstrated that PET detection is highly dependent on size, with metastases smaller than $5 \mathrm{~mm}$ being unlikely to be detected. MRI can detect lesions smaller than $5 \mathrm{~mm}$ but can also present false positives that require additional imaging to confirm. MRI may also miss the micro-metastases present in patients if they are in good neurological condition [120]. As well, some patients cannot undergo MRI, due to implants or metal foreign bodies, leaving these patients with a much poorer prognosis due to reliance on PET or CT to pick up their brain metastases. Recently, a paper was published suggesting a bifunctional aptamer can be used as a delivery vehicle to not only cross into the brain across the BBB, but also only target metastatic tumours derived from epithelial cancers once there. This aptamer combination firstly targets the transferrin receptor on the BBB to use receptor mediated transcytosis to non-invasively move across the BBB into the brain. The second arm of this aptamer uses the previously described EpA aptamer to then specifically target the tumour cells. When injected in a healthy animal model, this aptamer was able to accumulate in the brain within $10 \mathrm{~min}$ [119]. Further ongoing work with this aptamer is assessing its ability to act as a molecular imaging probe, which if successful, could pave the way for other targeted imaging agents to detect micro-metastases in the brain. The majority of these studies have investigated the specificity of these EpCAM aptamers to several different cell lines, representing a number of different cancer types, and suggest potential future directions for developing targeted therapeutics. There has also been some in vivo studies that suggest the efficacy and tolerability of these aptamers which make them well placed for further development.

Practical applications of aptamers in vivo demonstrated some challenges such as susceptibility to degradation by nucleases present in human serum and the rapid excretion by renal filtration [93]. In human serum, due to the presence of nucleases, both unmodified RNA and DNA aptamers are susceptible to degradation, with RNA being more sensitive due to the $2^{\prime}$ Hydroxyl group at the ribose location $[96,98]$. Fortunately, the short half-life of aptamers in human serum can be extended, as aptamers can easily be modified to increase resistance to exo- and endo-nuclease degradation [96]. The modified nucleotides can be introduced pre or post selection process via SELEX; with pre-selection having limited options due to incompatibility of modified nucleotides with the enzymatic steps of SELEX [98]. In comparison, post-selection modifications are easier and cheaper, but can negatively affect the binding properties and functionality of the aptamer [96,98].

A common method to prevent aptamer degradation by exo-nucleases, is to cap the $3^{\prime}$ - and /or $5^{\prime}$ - ends of the nucleic acid strands [121]. However, to increase stability to endonuclease-mediated degradation, the inter-nucleotide linkage can be modified with a phosphate backbone being substituted with sulfur to create a phosphorothioate linkage $[122,123]$. In the case of RNA based aptamers, the 
serum half-life and RNase resistance can be increased by modifying the highly nuclease susceptible $2^{\prime}$-hydroxyl group of the ribose sugar [96,98]. These modifications involve replacing the $2^{\prime}$-hydroxyl group with either fluoro $(\mathrm{F})$, alkyl, amino $\left(\mathrm{NH}_{2}\right)$ or thio group [124].

Since aptamers are relatively small molecules $(5-15 \mathrm{kDa})$, they are easily excreted by the kidneys [93]. Thus, renal filtration of aptamers leads to challenges in practical application due to the decreased circulation in the bloodstream [93]. A current solution to delay the excretion of aptamers from the bloodstream and improve aptamer pharmacokinetics, is conjugation with cholesterol or polyethylene glycol, termed PEGylation, to increase serum retention time of low molecular weight substances [93,122].

Table 4. Examples of targeting ligands that have a potential to bind with radioisotopes for diagnostic and therapeutic purposes.

\begin{tabular}{|c|c|c|c|c|}
\hline Ligands & Target Cells & Advantages & Disadvantages & References \\
\hline Albumin & Breast cancer cells & $\begin{array}{l}\text { Longer half-life, low } \\
\text { intrinsic activity, stable } \\
\text { to adverse } \mathrm{pH} \text { and } \\
\text { temperature }\end{array}$ & $\begin{array}{l}\text { Long circulatory half-life, } \\
\text { Accumulate in healthy } \\
\text { tissues. }\end{array}$ & {$[125,126]$} \\
\hline Antibodies & Multiple targets & $\begin{array}{c}\text { Targeted delivery of } \\
\text { drug }\end{array}$ & $\begin{array}{l}\text { Batch to batch variations, } \\
\text { cross reactivity }\end{array}$ & {$[127,128]$} \\
\hline Aptamers & Multiple targets & $\begin{array}{l}\text { Non immunogenic, } \\
\text { small in size }\end{array}$ & Rapid renal excretion & [93] \\
\hline Fibrinogen & Tumor vasculature & $\begin{array}{c}\text { Covalent linkage system } \\
\text { to provide control drug } \\
\text { release }\end{array}$ & $\begin{array}{l}\text { Not highly specific to the } \\
\text { receptor sites. }\end{array}$ & [129] \\
\hline Folate & Leukemia cells & $\begin{array}{c}\text { Receptor targeted } \\
\text { delivery with low level } \\
\text { of toxicity in normal } \\
\text { tissue }\end{array}$ & $\begin{array}{l}\text { Non-specific binding, pH } \\
\text { sensitive linkage }\end{array}$ & [130] \\
\hline Hyaluronic acid & CD44+ melanoma cells & Sustain release of drug & $\begin{array}{l}\text { Chemically un-stable in } \\
\text { body. }\end{array}$ & [131] \\
\hline Peptides & $\begin{array}{c}\text { Bombesin, } \\
\text { gastrin/cholecystokinin-2 }\end{array}$ & $\begin{array}{l}\text { Small in size, low } \\
\text { toxicity and highly } \\
\text { specific }\end{array}$ & $\begin{array}{l}\text { Higher proteolytic } \\
\text { in-stability }\end{array}$ & {$[91,132]$} \\
\hline
\end{tabular}

\section{Conclusions}

Although cancer is a leading cause of mortality globally, early diagnosis and detection can improve treatment outcomes due to early surgical, curative intervention. The challenges lie in present medical imaging and diagnostic techniques in oncology. While current medical imaging modalities can identify tumour masses, they are unable to specifically detect micrometastases before their angiogenesis stage, due to the minimum number of cells required for detection. PET molecular imaging has been able to improve detection of malignant cells, however, the typical use of FDG for pathological cells is non-specific for a disease, as normal tissues can uptake FDG which increases the background signal relative to the tumour. A number of different targeting ligands have been investigated in pre-clinical studies, though more work has been completed investigating antibodies and aptamers (Table 4). Antibody and peptide-based imaging has significantly improved molecular imaging, as it provides evidence to support the concept of targeting cancer surface molecules or biomarkers for highly specific and sensitive imaging of a pathology. However, both can interact with biological functions in vivo which can lead to adverse reactions, due to immunogenic responses. Therefore, with the advancement of nucleic acid chemistry, aptamers can be generated and modified to serve as molecular imaging agents with great specificity to a malignant cancer cell. Similar to antibodies, aptamers demonstrate great capacity to selectively and specifically bind to a cancer biomarker with high affinity to enable targeted imaging. In a similar process to radiolabelling antibodies, aptamers can be radiolabelled with radioisotopes such as gallium-68, to enable signal detection by PET/MRI scanners. In contrast to antibodies, aptamers offer numerous advantages: smaller size, greater stability 
and non-immunogenic nature in vivo. Limited work has been completed in this area but combining nuclear medicine techniques and radiolabeled aptamers will provide new opportunities to treat cancer at a cellular level or at a metastatic stage and provide opportunities for early diagnosis. Aptamers are an emerging frontier in medical molecular technology for cancer diagnostics and therapeutic applications. With their shared advantages and limited comparative disadvantages as compared to antibodies, it is hoped that aptamers will provide a better diagnostic and therapeutic option for patients in the future.

Funding: This research received no external funding.

Conflicts of Interest: The authors declare no conflict of interest.

\section{References}

1. Cooper, G. The Development and Causes of Cancer. In The Cell: A Molecular Approach, 2nd ed.; Sinauer Associates: Sunderland, MA, USA, 2000.

2. Martin, T.; Ye, L.; Sanderas, A.; Lane, J.; Jiang, W. Cancer Invasion and Metastasis: Molecular and Cellular Perspective. In Madame Curie Bioscience Database; Landes Bioscience: Austin, TX, USA, 2013.

3. Hussain, T.; Nguyen, Q.T. Molecular imaging for cancer diagnosis and surgery. Adv. Drug Deliv. Rev. 2014, 66, 90-100. [CrossRef]

4. Frangioni, J.V. New Technologies for Human Cancer Imaging. J. Clin. Oncol. 2008, 26, 4012-4021. [CrossRef]

5. Caschera, L.; Lazzara, A.; Piergallini, L.; Ricci, D.; Tuscano, B.; Vanzulli, A. Contrast agents in diagnostic imaging: Present and future. Pharmacol. Res. 2016, 110, 65-75. [CrossRef] [PubMed]

6. Sartor, O.; Maalouf, B.; Hauck, C.; Macklis, R. Targeted use of alpha particles: Current status in cancer therapeutics. J. Nucl. Med. Radiat. Ther. 2012, 3, 136-144.

7. Shukla, A.; Kumar, U. Positron emission tomography: An overview. J. Med. Phys. 2006, 31, 13-21. [CrossRef] [PubMed]

8. Goffin, K.; Van Laere, K. Single-photon emission tomography. In Handbook of Clinical Neurology; Elsevier: Amsterdam, The Netherlands, 2016; Volume 135, pp. 241-250.

9. Peck, M.; Pollack, H.; Friesen, A.; Muzi, M.; Shoner, S.; Shankland, E.; Fink, J.; Armstrong, J.; Link, J.; Krohn, K.A. Applications of PET imaging with the proliferation marker [18F]-FLT. Q. J. Nucl. Med. Mol. Imaging 2015, 59, 95-104. [PubMed]

10. Kurland, B.F.; Peterson, L.M.; Lee, J.H.; Schubert, E.K.; Currin, E.R.; Link, J.M.; Krohn, K.A.; Mankoff, D.A.; Linden, H.M. Estrogen receptor binding (18F-FES PET) and glycolytic activity (18F-FDG PET) predict progression-free survival on endocrine therapy in patients with ER+ breast cancer. Clin. Cancer Res. 2017, 23, 407-415. [CrossRef] [PubMed]

11. Peeters, S.G.; Zegers, C.M.; Lieuwes, N.G.; van Elmpt, W.; Eriksson, J.; van Dongen, G.A.; Dubois, L.; Lambin, P. A comparative study of the hypoxia PET tracers [18F] HX4, [18F] FAZA, and [18F] FMISO in a preclinical tumor model. Int. J. Radiat. Oncol. Biol. Phys. 2015, 91, 351-359. [CrossRef]

12. Bekaert, L.; Valable, S.; Lechapt-Zalcman, E.; Ponte, K.; Collet, S.; Constans, J.-M.; Levallet, G.; Bordji, K.; Petit, E.; Branger, P. [18F]-FMISO PET study of hypoxia in gliomas before surgery: Correlation with molecular markers of hypoxia and angiogenesis. Eur. J. Nucl. Med. Mol. Imaging 2017, 44, 1383-1392. [CrossRef]

13. Pasternak, J.J.; Williamson, E.E. Clinical Pharmacology, Uses, and Adverse Reactions of Iodinated Contrast Agents: A Primer for the Non-radiologist. Mayo Clin. Proc. 2012, 87, 390-402. [CrossRef]

14. Bellin, M.F.; Vasile, M.; Morel-Precetti, S. Currently used non-specific extracellular MR contrast media. Eur. Radiol. 2003, 13, 2688-2698. [CrossRef] [PubMed]

15. Dhingra, V.K.; Mahajan, A.; Basu, S. Emerging clinical applications of PET based molecular imaging in oncology: The promising future potential for evolving personalized cancer care. Indian J. Radiol. Imaging 2015, 25, 332-341. [PubMed]

16. Griffeth, L.K. Use of PET/CT scanning in cancer patients: Technical and practical considerations. Proc. (Bayl. Univ. Med. Cent.) 2005, 18, 321-330. [CrossRef] [PubMed]

17. Jadvar, H. FDG PET in Prostate Cancer. PET Clin. 2009, 4, 155-161. [CrossRef] [PubMed]

18. Chen, W.; Dong, J.; Haiech, J.; Kilhoffer, M.-C.; Zeniou, M. Cancer Stem Cell Quiescence and Plasticity as Major Challenges in Cancer Therapy. Stem Cells Int. 2016, 2016, 1740936. [CrossRef] [PubMed] 
19. Bollineni, V.; Kramer, G.; Jansma, E.; Liu, Y.; Oyen, W. A systematic review on [18F] FLT-PET uptake as a measure of treatment response in cancer patients. Eur. J. Cancer 2016, 55, 81-97. [CrossRef] [PubMed]

20. Raccagni, I.; Belloli, S.; Valtorta, S.; Stefano, A.; Presotto, L.; Pascali, C.; Bogni, A.; Tortoreto, M.; Zaffaroni, N.; Daidone, M.G. [18F] FDG and [18F] FLT PET for the evaluation of response to neo-adjuvant chemotherapy in a model of triple negative breast cancer. PLOS ONE 2018, 13, e0197754. [CrossRef] [PubMed]

21. Venema, C.M.; Mammatas, L.H.; Schröder, C.P.; van Kruchten, M.; Apollonio, G.; Glaudemans, A.W.; Bongaerts, A.H.; Hoekstra, O.S.; Verheul, H.M.; Boven, E. Androgen and estrogen receptor imaging in metastatic breast cancer patients as a surrogate for tissue biopsies. J. Nucl. Med. 2017, 58, 1906-1912. [CrossRef]

22. Paquette, M.; Lavallée, É.; Phoenix, S.; Ouellet, R.; Senta, H.; van Lier, J.E.; Guérin, B.; Lecomte, R.; Turcotte, É.E. Improved Estrogen Receptor Assessment by PET Using the Novel Radiotracer 18F-4FMFES in Estrogen Receptor-Positive Breast Cancer Patients: An Ongoing Phase II Clinical Trial. J. Nucl. Med. 2018, 59, 197-203. [CrossRef]

23. Tsujikawa, T.; Tsuyoshi, H.; Yamada, S.; Chino, Y.; Mori, T.; Kurokawa, T.; Kiyono, Y.; Okazawa, H. 18F-FES and 18F-FDG PET/MR imaging of gynecologic tumors: Initial experience in 5 cases. J. Nucl. Med. 2017, 58,1068 .

24. Zhao, S.; Yu, W.; Ukon, N.; Nishijima, K.-i.; Yamashita, H.; Tamaki, N.; Kuge, Y. Effects of eribulin on remodeling of tumor vasculature evaluated with 18F-FMISO hypoxia imaging in a human breast cancer cell xenograft. J. Nucl. Med. 2016, 57, 1350.

25. de Kruijff, R.M.; Wolterbeek, H.T.; Denkova, A.G. A critical review of alpha radionuclide therapy-How to deal with recoiling daughters? Pharmaceuticals 2015, 8, 321-336. [CrossRef] [PubMed]

26. Elgqvist, J.; Frost, S.; Pouget, J.-P.; Albertsson, P. The potential and hurdles of targeted alpha therapy-Clinical trials and beyond. Front. Oncol. 2014, 3, 324. [CrossRef] [PubMed]

27. van der Doelen, M.J.; Mehra, N.; Smits, M.; van Oort, I.M.; Janssen, M.J.; Haberkorn, U.; Kratochwil, C.; Gerritsen, W. Clinical experience with PSMA-Actinium-225 (Ac-225) radioligand therapy (RLT) in end-stage metastatic castration-resistant prostate cancer (mCRPC) patients. J. Clin. Oncol. 2018, 36, 344. [CrossRef]

28. Donya, M.; Radford, M.; El Guindy, A.; Firmin, D.; Yacoub, M.H. Radiation in medicine: Origins, risks and aspirations. Glob. Cardiol. Sci. Pract. 2014, 4, 437-448. [CrossRef] [PubMed]

29. Cheung, M.C.; Haynes, A.E.; Stevens, A.; Meyer, R.M.; Imrie, K. Yttrium 90 ibritumomab tiuxetan in lymphoma. Leuk. Lymphoma 2006, 47, 967-977. [CrossRef] [PubMed]

30. Faderl, S.; Kantarjian, H. Leukemias: Principles and Practice of Therapy; John Wiley \& Sons: Hoboken, NJ, USA, 2011.

31. Gulec, S.A.; Mesoloras, G.; Dezarn, W.A.; McNeillie, P.; Kennedy, A.S. Safety and efficacy of Y-90 microsphere treatment in patients with primary and metastatic liver cancer: The tumor selectivity of the treatment as a function of tumor to liver flow ratio. J. Transl. Med. 2007, 5, 15. [CrossRef] [PubMed]

32. Singh, P.; Anil, G. Yttrium-90 radioembolization of liver tumors: What do the images tell us? Cancer Imaging 2013, 13, 645. [CrossRef]

33. Michl, M.; Haug, A.; Jakobs, T.; Paprottka, P.; Hoffmann, R.-T.; Bartenstein, P.; Boeck, S.; Haas, M.; Laubender, R.P.; Heinemann, V. Radioembolization with Yttrium-90 microspheres (SIRT) in pancreatic cancer patients with liver metastases: Efficacy, safety and prognostic factors. Oncology 2014, 86, 24-32. [CrossRef]

34. Chandra, R.; Rahmim, A. Nuclear Medicine Physics: The Basics; Lippincott Williams \& Wilkins: Philadelphia, PA, USA, 2017.

35. Hine, G.J. Instrumentation in Nuclear Medicine; Academic Press: Cambridge, MA, USA, 2016.

36. Wangler, B.; Schirrmacher, R.; Bartenstein, P.; Wangler, C. Chelating agents and their use in radiopharmaceutical sciences. Mini Rev. Med. Chem. 2011, 11, 968-983. [CrossRef]

37. Price, E.W.; Orvig, C. Matching chelators to radiometals for radiopharmaceuticals. Chem. Soc. Rev. 2014, 43, 260-290. [CrossRef] [PubMed]

38. Liu, Y.; Liu, G.; Hnatowich, D.J. A brief review of chelators for radiolabeling oligomers. Materials 2010, 3 , 3204-3217. [CrossRef]

39. Pysz, M.A.; Gambhir, S.S.; Willmann, J.K. Molecular imaging: Current status and emerging strategies. Clin. Radiol. 2010, 65, 500-516. [CrossRef] [PubMed] 
40. Wu, A.M. Engineered antibodies for molecular imaging of cancer. Methods (San Diego Calif.) 2014, 65, $139-147$. [CrossRef] [PubMed]

41. Scott, A.M.; Allison, J.P.; Wolchok, J.D. Monoclonal antibodies in cancer therapy. Cancer Immun. 2012, $12,14$. [PubMed]

42. Fleuren, E.D.; Versleijen-Jonkers, Y.M.; Heskamp, S.; Van Herpen, C.M.; Oyen, W.J.; Van Der Graaf, W.T.; Boerman, O.C. Theranostic applications of antibodies in oncology. Mol. Oncol. 2014, 8, 799-812. [CrossRef]

43. Warram, J.M.; de Boer, E.; Sorace, A.G.; Chung, T.K.; Kim, H.; Pleijhuis, R.G.; van Dam, G.M.; Rosenthal, E.L. Antibody-based imaging strategies for cancer. Cancer Metastasis Rev. 2014, 33, 809-822. [CrossRef]

44. Röthlisberger, P.; Gasse, C.; Hollenstein, M. Nucleic Acid Aptamers: Emerging Applications in Medical Imaging, Nanotechnology, Neurosciences, and Drug Delivery. Int. J. Mol. Sci. 2017, 18, 2430. [CrossRef]

45. Banerjee, S.R.; Pomper, M.G. Clinical applications of Gallium-68. Appl. Radiat. Isot. 2013, 76, 2-13. [CrossRef]

46. Yang, Y.; Hernandez, R.; Rao, J.; Yin, L.; Qu, Y.; Wu, J.; England, C.G.; Graves, S.A.; Lewis, C.M.; Wang, P. Targeting CD146 with a 64Cu-labeled antibody enables in vivo immunoPET imaging of high-grade gliomas. Proc. Natl. Acad. Sci. USA 2015, 112, e6525-e6534. [CrossRef]

47. Wang, P.; Qu, Y.; Li, C.; Yin, L.; Shen, C.; Chen, W.; Yang, S.; Bian, X.; Fang, D. Bio-functionalized dense-silica nanoparticles for MR/NIRF imaging of CD146 in gastric cancer. Int. J. Nanomed. 2015, 10, 749. [CrossRef]

48. Sun, H.; England, C.G.; Hernandez, R.; Graves, S.A.; Majewski, R.L.; Kamkaew, A.; Jiang, D.; Barnhart, T.E.; Yang, Y.; Cai, W. ImmunoPET for assessing the differential uptake of a CD146-specific monoclonal antibody in lung cancer. Eur. J. Nucl. Med. Mol. Imaging 2016, 43, 2169-2179. [CrossRef] [PubMed]

49. Frigerio, B.; Franssen, G.; Luison, E.; Satta, A.; Seregni, E.; Colombatti, M.; Fracasso, G.; Valdagni, R.; Mezzanzanica, D.; Boerman, O. Full preclinical validation of the 123I-labeled anti-PSMA antibody fragment ScFvD2B for prostate cancer imaging. Oncotarget 2017, 8, 10919. [CrossRef] [PubMed]

50. Wibmer, A.G.; Burger, I.A.; Sala, E.; Hricak, H.; Weber, W.A.; Vargas, H.A. Molecular imaging of prostate cancer. Radiographics 2015, 36, 142-159. [CrossRef] [PubMed]

51. Pandit-Taskar, N.; O’Donoghue, J.A.; Divgi, C.R.; Wills, E.A.; Schwartz, L.; Gönen, M.; Smith-Jones, P.; Bander, N.H.; Scher, H.I.; Larson, S.M. Indium 111-labeled J591 anti-PSMA antibody for vascular targeted imaging in progressive solid tumors. EJNMMI Res. 2015, 5, 28. [CrossRef] [PubMed]

52. Rahbar, K.; Ahmadzadehfar, H.; Kratochwil, C.; Haberkorn, U.; Schafers, M.; Essler, M.; Baum, R.P.; Kulkarni, H.R.; Schmidt, M.; Drzezga, A. German multicenter study investigating 177Lu-PSMA-617 radioligand therapy in advanced prostate cancer patients. J. Nucl. Med. 2017, 58, 85-90. [CrossRef] [PubMed]

53. Mortimer, J.E.; Bading, J.R.; Park, J.M.; Frankel, P.H.; Carroll, M.I.; Tran, T.T.; Poku, E.K.; Rockne, R.C.; Raubitschek, A.A.; Shively, J.E. Tumor uptake of 64Cu-DOTA-trastuzumab in patients with metastatic breast cancer. J. Nucl. Med. 2018, 59, 38. [CrossRef] [PubMed]

54. Mortimer, J.E.; Bading, J.R.; Colcher, D.M.; Conti, P.S.; Frankel, P.H.; Carroll, M.I.; Tong, S.; Poku, E.; Miles, J.K.; Shively, J.E. Functional imaging of HER2-positive metastatic breast cancer using 64Cu-DOTA-trastuzumab positron emission tomography. J. Nucl. Med. Off. Publ. Soc. Nucl. Med. 2014, 55, 23.

55. Laforest, R.; Lapi, S.E.; Oyama, R.; Bose, R.; Tabchy, A.; Marquez-Nostra, B.V.; Burkemper, J.; Wright, B.D.; Frye, J.; Frye, S. [89 Zr] Trastuzumab: Evaluation of Radiation Dosimetry, Safety, and Optimal Imaging Parameters in Women with HER2-Positive Breast Cancer. Mol. Imaging Biol. 2016, 18, 952-959. [CrossRef] [PubMed]

56. Ulaner, G.A.; Hyman, D.M.; Ross, D.S.; Corben, A.; Chandarlapaty, S.; Goldfarb, S.; McArthur, H.; Erinjeri, J.P.; Solomon, S.B.; Kolb, H. Detection of HER2-positive metastases in patients with HER2-negative primary breast cancer using 89Zr-trastuzumab PET/CT. J. Nucl. Med. 2016, 57, 1523. [CrossRef]

57. Jauw, Y.W.; Hoekstra, O.S.; Hendrikse, N.H.; Vugts, D.J.; Zijlstra, J.M.; Huisman, M.C.; van Dongen, G.A. Immuno-positron emission tomography with zirconium-89-labeled monoclonal antibodies in oncology: What can we learn from initial clinical trials? Front. Pharmacol. 2016, 7, 131. [CrossRef] [PubMed]

58. Rudnick, S.I.; Adams, G.P. Affinity and avidity in antibody-based tumor targeting. Cancer Biother. Radiopharm. 2009, 24, 155-161. [CrossRef] [PubMed]

59. Steiner, M.; Neri, D. Antibody-radionuclide conjugates for cancer therapy: Historical considerations and new trends. Clin. Cancer Res. 2011, 17, 6406-6416. [CrossRef] [PubMed] 
60. Kukis, D.L.; DeNardo, G.L.; DeNardo, S.J.; Mirick, G.R.; Miers, L.A.; Greiner, D.P.; Meares, C.F. Effect of the extent of chelate substitution on the immunoreactivity and biodistribution of 2IT-BAT-Lym-1 immunoconjugates. Cancer Res. 1995, 55, 878-884.

61. Anderes, E.; Nand, S. Commonly used drugs in hematologic disorders. In Handbook of Clinical Neurology; Elsevier: Amsterdam, The Netherlands, 2014; Volume 120, pp. 1125-1139.

62. D'huyvetter, M.; Vincke, C.; Xavier, C.; Aerts, A.; Impens, N.; Baatout, S.; De Raeve, H.; Muyldermans, S.; Caveliers, V.; Devoogdt, N. Targeted radionuclide therapy with A 177Lu-labeled anti-HER2 nanobody. Theranostics 2014, 4, 708. [CrossRef] [PubMed]

63. Revskaya, E.; Jiang, Z.; Morgenstern, A.; Bruchertseifer, F.; Sesay, M.; Walker, S.; Fuller, S.; Lebowitz, M.S.; Gravekamp, C.; Ghanbari, H.A. A Radiolabeled Fully Human Antibody to Human Aspartyl (Asparaginyl) $\beta$-Hydroxylase Is a Promising Agent for Imaging and Therapy of Metastatic Breast Cancer. Cancer Biother. Radiopharm. 2017, 32, 57-65. [CrossRef]

64. Hermanto, S.; Haryuni, R.D.; Ramli, M.; Mutalib, A.; Hudiyono, S. Synthesis and stability test of radioimmunoconjugate 177Lu-DOTA-F $\left(\mathrm{ab}^{\prime}\right)$ 2-trastuzumab for theranostic agent of HER2 positive breast cancer. J. Radiat. Res. Appl. Sci. 2016, 9, 441-448. [CrossRef]

65. Kraeber-Bodéré, F.; Bodet-Milin, C.; Rousseau, C.; Eugène, T.; Pallardy, A.; Frampas, E.; Carlier, T.; Ferrer, L.; Gaschet, J.; Davodeau, F.; et al. Radioimmunoconjugates for the Treatment of Cancer. Semin. Oncol. 2014, 41, 613-622.

66. Olafsen, T.; Wu, A.M. Antibody Vectors for Imaging. Semin. Nucl. Med. 2010, 40, 167-181. [CrossRef]

67. Collin de l'Hortet, A.; Gilgenkrantz, H.; Guidotti, J.-E. EGFR: A master piece in G1/S phase transition of liver regeneration. Int. J. Hepatol. 2012, 2012. [CrossRef]

68. Tolmachev, V.; Friedman, M.; Sandstrom, M.; Eriksson, T.L.; Rosik, D.; Hodik, M.; Stahl, S.; Frejd, F.Y.; Orlova, A. Affibody molecules for epidermal growth factor receptor targeting in vivo: Aspects of dimerization and labeling chemistry. J. Nucl. Med. 2009, 50, 274. [CrossRef]

69. Fosgerau, K.; Hoffmann, T. Peptide therapeutics: Current status and future directions. Drug Discov. Today 2015, 20, 122-128. [CrossRef] [PubMed]

70. Vegt, E.; De Jong, M.; Wetzels, J.F.; Masereeuw, R.; Melis, M.; Oyen, W.J.; Gotthardt, M.; Boerman, O.C. Renal toxicity of radiolabeled peptides and antibody fragments: Mechanisms, impact on radionuclide therapy, and strategies for prevention. J. Nucl. Med. 2010, 51, 1049-1058. [CrossRef] [PubMed]

71. Thundimadathil, J. Cancer treatment using peptides: Current therapies and future prospects. J. Amino Acids 2012, 2012. [CrossRef] [PubMed]

72. Rufini, V.; Calcagni, M.L.; Baum, R.P. Imaging of Neuroendocrine Tumors; Seminars in Nuclear Medicine; Elsevier: Amsterdam, The Netherlands, 2006; pp. 228-247.

73. Virgolini, I.; Traub, T.; Novotny, C.; Leimer, M.; Fuger, B.; Li, S.; Patri, P.; Pangerl, T.; Angelberger, P.; Raderer, M. Experience with indium-111 and yttrium-90-labeled somatostatin analogs. Curr. Pharm. Des. 2002, 8, 1781-1807. [CrossRef] [PubMed]

74. Bushnell, D.L.; Menda, Y.; Madsen, M.T.; Link, B.K.; Kahn, D.; Truhlar, S.M.; Juweid, M.; Shannon, M.; Murguia, J.S. 99mTc-depreotide tumour uptake in patients with non-Hodgkin's lymphoma. Nucl. Med. Commun. 2004, 25, 839-843. [CrossRef] [PubMed]

75. Esser, J.-P.; Krenning, E.; Teunissen, J.; Kooij, P.; Van Gameren, A.; Bakker, W.; Kwekkeboom, D.J. Comparison of [177 Lu-DOTA 0, Tyr 3] octreotate and [177 Lu-DOTA 0, Tyr 3] octreotide: Which peptide is preferable for PRRT? Eur. J. Nucl. Med. Mol. Imaging 2006, 33, 1346-1351. [CrossRef] [PubMed]

76. Jackson, I.M.; Scott, P.J.H.; Thompson, S. Clinical Applications of Radiolabeled Peptides for PET. Semin. Nucl. Med. 2017, 47, 493-523. [CrossRef]

77. Wester, H.J.; Keller, U.; Schottelius, M.; Beer, A.; Philipp-Abbrederis, K.; Hoffmann, F.; Šimeček, J.; Gerngross, C.; Lassmann, M.; Herrmann, K. Disclosing the CXCR4 expression in lymphoproliferative diseases by targeted molecular imaging. Theranostics 2015, 5, 618. [CrossRef]

78. Shoeib, M.; Saeed, S.; Alireza, M.A.; Soroush, S. Peptidomimetics and their Applications in Antifungal Drug Design. Anti-Infect. Agents Med. Chem. 2009, 8, 327-344.

79. Gibbons, J.A.; Hancock, A.A.; Vitt, C.R.; Knepper, S.; Buckner, S.A.; Brune, M.E.; Milicic, I.; Kerwin, J.; Richter, L.S.; Taylor, E.W. Pharmacologic characterization of CHIR 2279, an N-substituted glycine peptoid with high-affinity binding for alpha 1-adrenoceptors. J. Pharmacol. Exp. Ther. 1996, 277, 885-899. 
80. Baum, R.P.; Kulkarni, H.R.; Müller, D.; Satz, S.; Danthi, N.; Kim, Y.-S.; Brechbiel, M.W. First-in-human study demonstrating tumor-angiogenesis by PET/CT imaging with 68Ga-NODAGA-THERANOST, a high-affinity peptidomimetic for $\alpha \mathrm{v} \beta 3$ integrin receptor targeting. Cancer Biother. Radiopharm. 2015, 30, 152-159. [CrossRef] [PubMed]

81. U.S. National Library of Medicine. PET/CT Imaging of Angiogenesis in Patients with Neuroendocrine Tumors Using 68Ga-NODAGA-E[c(RGDyK)]2. Available online: https://clinicaltrials.gov/ct2/show/ NCT03271281?term=nodaga\&rank=4 (accessed on 30 November 2018).

82. Afshar-Oromieh, A.; Avtzi, E.; Giesel, F.L.; Holland-Letz, T.; Linhart, H.G.; Eder, M.; Eisenhut, M.; Boxler, S.; Hadaschik, B.A.; Kratochwil, C.; et al. The diagnostic value of PET/CT imaging with the (68)Ga-labelled PSMA ligand HBED-CC in the diagnosis of recurrent prostate cancer. Eur. J. Nucl. Med. Mol. Imaging 2015, 42, 197-209. [CrossRef] [PubMed]

83. Giesel, F.L.; Knorr, K.; Spohn, F.; Will, L.; Maurer, T.; Flechsig, P.; Neels, O.; Schiller, K.; Amaral, H.; Weber, W.; et al. Detection efficacy of [18F]PSMA-1007 PET/CT in 251 Patients with biochemical recurrence after radical prostatectomy. J. Nucl. Med. 2018. [CrossRef] [PubMed]

84. Rathke, H.; Giesel, F.L.; Flechsig, P.; Kopka, K.; Mier, W.; Hohenfellner, M.; Haberkorn, U.; Kratochwil, C. Repeated 177Lu-Labeled PSMA-617 Radioligand Therapy Using Treatment Activities of Up to 9.3 GBq. J. Nucl. Med. 2018, 59, 459-465. [CrossRef] [PubMed]

85. Calais, J.; Kishan, A.U.; Cao, M.; Fendler, W.P.; Eiber, M.; Herrmann, K.; Ceci, F.; Reiter, R.E.; Rettig, M.B.; Hegde, J.V.; et al. Potential Impact of 68Ga-PSMA-11 PET/CT on the Planning of Definitive Radiation Therapy for Prostate Cancer. J. Nucl. Med. 2018, 59, 1714-1721. [CrossRef] [PubMed]

86. De Visschere, P.J.L.; Standaert, C.; Fütterer, J.J.; Villeirs, G.M.; Panebianco, V.; Walz, J.; Maurer, T.; Hadaschik, B.A.; Lecouvet, F.E.; Giannarini, G.; et al. A Systematic Review on the Role of Imaging in Early Recurrent Prostate Cancer. Eur. Urol. Oncol. 2018. [CrossRef]

87. Hofman, M.S.; Violet, J.; Hicks, R.J.; Ferdinandus, J.; Thang, S.P.; Akhurst, T.; Iravani, A.; Kong, G.; Ravi Kumar, A.; Murphy, D.G.; et al. [(177)Lu]-PSMA-617 radionuclide treatment in patients with metastatic castration-resistant prostate cancer (LuPSMA trial): A single-centre, single-arm, phase 2 study. Lancet Oncol. 2018, 19, 825-833. [CrossRef]

88. Akram, O.N.; Bursill, C.; Desai, R.; Heather, A.K.; Kazlauskas, R.; Handelsman, D.J.; Lambert, G. Evaluation of androgenic activity of nutraceutical-derived steroids using mammalian and yeast in vitro androgen bioassays. Anal. Chem. 2011, 83, 2065-2074. [CrossRef]

89. Powell, S.; Christiaens, V.; Voulgaraki, D.; Waxman, J.; Claessens, F.; Bevan, C. Mechanisms of androgen receptor signalling via steroid receptor coactivator-1 in prostate. Endocr.-Relat. Cancer 2004, 11, 117-130. [CrossRef]

90. Akram, O.N.; DeGraff, D.J.; Sheehan, J.H.; Tilley, W.D.; Matusik, R.J.; Ahn, J.-M.; Raj, G.V. Tailoring peptidomimetics for targeting protein-protein interactions. Mol. Cancer Res. 2014, 12, 967-978. [CrossRef]

91. Otvos, L., Jr.; Wade, J.D. Current challenges in peptide-based drug discovery. Front. Chem. $2014,2,62$. [CrossRef] [PubMed]

92. Shigdar, S.; Lin, J.; Yu, Y.; Pastuovic, M.; Wei, M.; Duan, W. RNA aptamer against a cancer stem cell marker epithelial cell adhesion molecule. Cancer Sci. 2011, 102, 991-998. [CrossRef] [PubMed]

93. Lakhin, A.V.; Tarantul, V.Z.; Gening, L.V. Aptamers: Problems, solutions and prospects. Acta Nat. 2013, 5, 34-43.

94. Hays, E.M.; Duan, W.; Shigdar, S. Aptamers and Glioblastoma: Their Potential Use for Imaging and Therapeutic Applications. Int. J. Mol. Sci. 2017, 18, 2576. [CrossRef] [PubMed]

95. Tuerk, C.; Gold, L. Systematic evolution of ligands by exponential enrichment: RNA ligands to bacteriophage T4 DNA polymerase. Science 1990, 249, 505-510. [CrossRef] [PubMed]

96. Shigdar, S.; Macdonald, J.; O'Connor, M.; Wang, T.; Xiang, D.; Al Shamaileh, H.; Qiao, L.; Wei, M.; Zhou, S.F.; Zhu, Y.; et al. Aptamers as theranostic agents: Modifications, serum stability and functionalisation. Sensors 2013, 13, 13624-13637. [CrossRef] [PubMed]

97. Ellington, A.D.; Szostak, J.W. In vitro selection of RNA molecules that bind specific ligands. Nature 1990, 346, 818. [CrossRef]

98. Gijs, M.; Aerts, A.; Impens, N.; Baatout, S.; Luxen, A. Aptamers as radiopharmaceuticals for nuclear imaging and therapy. Nucl. Med. Biol. 2016, 43, 253-271. [CrossRef] 
99. Wang, A.Z.; Farokhzad, O.C. Current Progress of Aptamer-Based Molecular Imaging. J. Nucl. Med. 2014, 55, 353-356. [CrossRef]

100. Lee, J.W.; Kim, H.J.; Heo, K. Therapeutic aptamers: Developmental potential as anticancer drugs. BMB Rep. 2015, 48, 234-237. [CrossRef]

101. Xiang, D.; Zheng, C.; Zhou, S.F.; Qiao, S.; Tran, P.H.; Pu, C.; Li, Y.; Kong, L.; Kouzani, A.Z.; Lin, J.; et al. Superior Performance of Aptamer in Tumor Penetration over Antibody: Implication of Aptamer-Based Theranostics in Solid Tumors. Theranostics 2015, 5, 1083-1097. [CrossRef]

102. Macdonald, J.; Henri, J.; Roy, K.; Hays, E.; Bauer, M.; Veedu, R.N.; Pouliot, N.; Shigdar, S. EpCAM Immunotherapy versus Specific Targeted Delivery of Drugs. Cancers 2018, 10, 19. [CrossRef]

103. Hicke, B.J.; Stephens, A.W.; Gould, T.; Chang, Y.; Lynott, C.K.; Heil, J.; Borkowski, S.; Hilger, C.; Cook, G.; Warren, S. Tumor targeting by an aptamer. J. Nucl. Med. 2006, 47, 668.

104. Da Pieve, C.; Perkins, A.C.; Missailidis, S. Anti-MUC1 aptamers: Radiolabelling with 99mTc and biodistribution in MCF-7 tumour-bearing mice. Nucl. Med. Biol. 2009, 36, 703-710. [CrossRef] [PubMed]

105. Kryza, D.; Debordeaux, F.; Azéma, L.; Hassan, A.; Paurelle, O.; Schulz, J.; Savona-Baron, C.; Charignon, E.; Bonazza, P.; Taleb, J. Ex vivo and in vivo imaging and biodistribution of aptamers targeting the human matrix metalloprotease-9 in melanomas. PLOS ONE 2016, 11, e0149387. [CrossRef] [PubMed]

106. Yoon, S.; Rossi, J. Targeted molecular imaging using aptamers in cancer. Pharmaceuticals 2018, $11,71$. [CrossRef]

107. Li, J.; Zheng, H.; Trent, J.; Bates, P.; Ng, C.K. Evaluation of 64Cu-DOTA-AS1411 as a PET tracer for lung cancer imaging. J. Nucl. Med. 2009, 50, 1915.

108. Li, J.; Zheng, H.; Bates, P.J.; Malik, T.; Li, X.-F.; Trent, J.O.; Ng, C.K. Aptamer imaging with Cu-64 labeled AS1411: Preliminary assessment in lung cancer. Nucl. Med. Biol. 2014, 41, 179-185. [CrossRef] [PubMed]

109. Zhu, G.; Zhang, H.; Jacobson, O.; Wang, Z.; Chen, H.; Yang, X.; Niu, G.; Chen, X. Combinatorial screening of DNA aptamers for molecular imaging of HER2 in cancer. Bioconj. Chem. 2017, 28, 1068-1075. [CrossRef] [PubMed]

110. Emmett, L.; Willowson, K.; Violet, J.; Shin, J.; Blanksby, A.; Lee, J. Lutetium (177) PSMA radionuclide therapy for men with prostate cancer: A review of the current literature and discussion of practical aspects of therapy. J. Med. Radiat. Sci. 2017, 64, 52-60. [CrossRef] [PubMed]

111. Trzpis, M.; McLaughlin, P.M.; de Leij, L.M.; Harmsen, M.C. Epithelial cell adhesion molecule: More than a carcinoma marker and adhesion molecule. Am. J. Pathol. 2007, 171, 386-395. [CrossRef] [PubMed]

112. Maetzel, D.; Denzel, S.; Mack, B.; Canis, M.; Went, P.; Benk, M.; Kieu, C.; Papior, P.; Baeuerle, P.A.; Munz, M.; et al. Nuclear signalling by tumour-associated antigen EpCAM. Nat. Cell Biol. 2009, 11, 162-171. [CrossRef] [PubMed]

113. van der Gun, B.T.; Melchers, L.J.; Ruiters, M.H.; de Leij, L.F.; McLaughlin, P.M.; Rots, M.G. EpCAM in carcinogenesis: The good, the bad or the ugly. Carcinogenesis 2010, 31, 1913-1921. [CrossRef] [PubMed]

114. Schmidt, M.; Scheulen, M.E.; Dittrich, C.; Obrist, P.; Marschner, N.; Dirix, L.; Ruttinger, D.; Schuler, M.; Reinhardt, C.; Awada, A. An open-label, randomized phase II study of adecatumumab, a fully human anti-EpCAM antibody, as monotherapy in patients with metastatic breast cancer. Ann. Oncol. 2010, 21, 275-282. [CrossRef] [PubMed]

115. Soysal, S.D.; Muenst, S.; Barbie, T.; Fleming, T.; Gao, F.; Spizzo, G.; Oertli, D.; Viehl, C.T.; Obermann, E.C.; Gillanders, W.E. EpCAM expression varies significantly and is differentially associated with prognosis in the luminal B HER2(+), basal-like, and HER2 intrinsic subtypes of breast cancer. Br. J. Cancer 2013, 108, 1480-1487. [CrossRef] [PubMed]

116. Suzuki, Y.; Iida, M.; Miura, I.; Inubushi, T.; Morikawa, S. A Polymer-Based Magnetic Resonance Tracer for Visualization of Solid Tumors by 13C Spectroscopic Imaging. PLoS ONE 2014, 9, e102132. [CrossRef] [PubMed]

117. Alshaer, W.; Ababneh, N.; Hatmal, M.; Izmirli, H.; Choukeife, M.; Shraim, A.; Sharar, N.; Abu-Shiekah, A.; Odeh, F.; Al Bawab, A.; et al. Selection and targeting of EpCAM protein by ssDNA aptamer. PLoS ONE 2017, 12, e0189558. [CrossRef]

118. Song, Y.; Zhu, Z.; An, Y.; Zhang, W.; Zhang, H.; Liu, D.; Yu, C.; Duan, W.; Yang, C.J. Selection of DNA Aptamers against Epithelial Cell Adhesion Molecule for Cancer Cell Imaging and Circulating Tumor Cell Capture. Anal. Chem. 2013, 85, 4141-4149. [CrossRef] 
119. Macdonald, J.; Henri, J.; Goodman, L.; Xiang, D.; Duan, W.; Shigdar, S. Development of a Bifunctional Aptamer Targeting the Transferrin Receptor and Epithelial Cell Adhesion Molecule (EpCAM) for the Treatment of Brain Cancer Metastases. ACS Chem. Neurosci. 2017, 8, 777-784. [CrossRef]

120. Deuschl, C.; Nensa, F.; Grueneisen, J.; Poeppel, T.D.; Sawicki, L.M.; Heusch, P.; Gramsch, C.; Mönninghoff, C.; Quick, H.H.; Forsting, M.; et al. Diagnostic impact of integrated 18F-FDG PET/MRI in cerebral staging of patients with non-small cell lung cancer. Acta Radiol. 2017, 58, 991-996. [CrossRef]

121. Ni, S.; Yao, H.; Wang, L.; Lu, J.; Jiang, F.; Lu, A.; Zhang, G. Chemical Modifications of Nucleic Acid Aptamers for Therapeutic Purposes. Int. J. Mol. Sci. 2017, 18, 1683. [CrossRef] [PubMed]

122. Ni, X.; Castanares, M.; Mukherjee, A.; Lupold, S.E. Nucleic acid aptamers: Clinical applications and promising new horizons. Curr. Med. Chem. 2011, 18, 4206-4214. [CrossRef] [PubMed]

123. Kong, H.Y.; Byun, J. Nucleic Acid Aptamers: New Methods for Selection, Stabilization, and Application in Biomedical Science. Biomol. Ther. 2013, 21, 423-434. [CrossRef] [PubMed]

124. Zhou, J.; Rossi, J. Aptamers as targeted therapeutics: Current potential and challenges. Nat. Rev. Drug Discov. 2016, 16, 181. [CrossRef] [PubMed]

125. Sleep, D. Albumin and its application in drug delivery. Expert Opin. Drug Deliv. 2015, 12, 793-812. [CrossRef]

126. Larsen, M.T.; Kuhlmann, M.; Hvam, M.L.; Howard, K.A. Albumin-based drug delivery: Harnessing nature to cure disease. Mol. Cell. Ther. 2016, 4, 3. [CrossRef]

127. Schonbrunn, A. Editorial: Antibody Can Get It Right: Confronting Problems of Antibody Specificity and Irreproducibility. Mol. Endocrinol. 2014, 28, 1403-1407. [CrossRef]

128. Baker, M. Reproducibility crisis: Blame it on the antibodies. Nat. News 2015, 521, 274. [CrossRef]

129. Spicer, P.P.; Mikos, A.G. Fibrin glue as a drug delivery system. J. Control. Release 2010, 148, 49-55. [CrossRef]

130. Cheung, A.; Bax, H.J.; Josephs, D.H.; Ilieva, K.M.; Pellizzari, G.; Opzoomer, J.; Bloomfield, J.; Fittall, M.; Grigoriadis, A.; Figini, M. Targeting folate receptor alpha for cancer treatment. Oncotarget 2016, 7, 52553. [CrossRef]

131. Huang, G.; Huang, H. Application of hyaluronic acid as carriers in drug delivery. Drug Deliv. 2018, 25, 766-772. [CrossRef] [PubMed]

132. Opalinska, M.; Hubalewska-Dydejczyk, A.; Sowa-Staszczak, A. Radiolabeled peptides: Current and new perspectives. Q. J. Nucl. Med. Mol. Imaging 2017, 61, 153-167. [PubMed]

(C) 2018 by the authors. Licensee MDPI, Basel, Switzerland. This article is an open access article distributed under the terms and conditions of the Creative Commons Attribution (CC BY) license (http:/ / creativecommons.org/licenses/by/4.0/). 